\title{
Ordtoner i det norske talespråket til utenlandske studenter med tysk som førstespråk. En akustisk studie og et didaktisk perspektiv.
}

\section{Liv Andlem Harnaes \\ Institutt for lingvistiske og nordiske studier (ILN), UiO}

l.a.harnas@iln.uio.no

\section{Innledning}

Denne artikkelen er inspirert av to tidligere artikler i Nordand (Steien 2014; Kuronen 2015). I begge artiklene studeres ordtoner hos S2-talere. Både Kuronen og Steien bruker henholdsvis accent 1 og accent 2 og aksent 1 og aksent $2 \mathrm{om}$ den kontrastive tonegangen som finnes i de fleste varieteter av svensk og norsk (Hognestad 2012; Kristoffersen 2000), og som i norsk faglitteratur gjerne er blitt kalt tonemer eller tonelag, se for eksempel artikler i Jahr og Lorentz (1983). For å støtte opp om en felles skandinavisk terminologi når det gjelder gransking av ordtonekontraster i S2, velger jeg også å bruke termene aksent 1 og aksent 2 (uttalt $/ \mathrm{ak}^{1} \operatorname{sent} /$ ) om de to kontrastive norske ordtonene.

I Norge er det vanlig å eksemplifisere de to ordaksentene med ordene bønder /bønər/ og bønner /²bønər/. I talespråk er de to aksentene som regel ikke bundet til enkeltord, men til tonegangen i ulike aksentfraser, som defineres som avgrenset i begge retninger av en hovedtrykkstavelses begynnelse. En aksentfrase, AP, kan inneholde ulikt antall trykklette stavelser og flere enn ett ord. Den første (venstre) hovedtrykkstavelsen er del av en gitt AP, mens den neste (høyre) hovedtrykkstavelsens begynnelse blir begynnelsen av neste AP (Hognestad 2012:10; se også Kristoffersen 2000:190-191). En ny AP starter altså på en stavelse med hovedtrykk.

I spontan tale blir de såkalte ordaksentene også en del av setningsprosodien, intonasjonen, som organiseres i APer. Intonasjonen justerer eller modererer toneaksentkurvene. De to toneaksentene har i seg selv ingen betydning, men de skiller mellom ellers likelydende ord, og de innordnes det meningsbærende prosodiske systemet gjennom intonasjonen. En ytringsavsluttende aksentfrase slutter ofte på en høy grensetone, $\mathrm{H} \%$, i østnorsk. Det kan for eksempel føre til at fortellende setninger oppfattes som spørsmål av utlendinger. I en artikkel om grensetoner i imperativer i østnorsk viser Fretheim og van Dommelen (2012) at lav grensetone, $\mathrm{L} \%$, gjør imperativene vennligere, mens en høy grensetone gjør dem mer imperative og bydende. Selv om ytringsavsluttende APer vil inngå i min undersøkelse, vil meningsformidlingen som ligger i det prosodiske systemet og spesielt i tonegangen, berøres i liten grad.

I granskningen av toneaksentene har jeg inkludert hele aksentfrasen, men både de tyske og de norske talerne avsluttet aksentfrasene ulikt slik at tonekurven i siste del av aksentfrasen kom til å strekke seg over ulikt antall stavelser eller ord. Hovedfokus i denne artikkelen er en beskrivelse og sammenlikning av tonebevegelsen i trykksterk stavelse i de to toneaksentene, men grensetoner og tonegangen i de trykklette stavelsene i aksentfrasen vil bli kommentert. 
Sju utenlandske studenter med tysk som førstespråk har deltatt i min studie. De gikk alle på norskkurs på trinn 3 ved Institutt for lingvistiske og nordiske studier (ILN) ved Universitetet i Oslo (UiO) da opptakene ble gjort i april måned 2016, det vil si på slutten av kurset. Ingen av dem har fått systematisk uttaleundervisning i norsk prosodi utover det den enkelte lærer kan ha tatt opp i kurstimene. I artikkelens avslutning vil resultatene av toneundersøkelsene bli vurdert i forhold til uttaleopplæring i norsk som andrespråk: I hvilken grad og eventuelt hvordan kan toneaksentene inngå som en del av uttaleundervisningen? Artikkelens hovedproblemstilling vil være en empirisk unders $\varnothing$ kelse av tonegangen til de sju S2-talerne i de utvalgte aksentfrasene.

\section{Studier av tilegnelse av intonasjon og ordtoner i S2}

Språk som utnytter grunntonevariasjonen, f0, til å skille mellom ord, inndeles gjerne i toneaksentspråk (eng. pitch accent languages, som f.eks. svensk og norsk) og tonespråk (eng. tone languages, som f.eks. vietnamesisk, mandarin og kantonesisk) (se f.eks. Husby \& Kløve 2001:93ff). Toneaksentspråk og tonespråk har ulike tonesystemer, men man kan tenke seg at det må være fellestrekk ved innlæring for en som ikke er vant med ordskillende toner.

Det er særlig i de asiatiske tonespråkene at både persepsjon og produksjon av tone hos L2-talere har blitt utforsket (jf. van Dommelen \& Husby 2009). Resultater kan tyde på at det er lettere for S1-talere av tonespråk å kjenne igjen tonene i et annet tonespråk. Auditive øvelser har vist seg å ha en positiv effekt på evnen til å uttale ulike toner. Dessuten tyder unders $\emptyset$ kelser på at nivåtoner er vanskeligere å produsere enn konturtoner (Wang m.fl. 2003; se også Husby \& Kløve 2001:94). (For en mer teoretisk drøfting av prosodi og andrespråkstilegnelse se Steien 2014.)

Tilegnelse av intonasjon og toner i mellomspråksnorsk er lite utforsket. Jan Kristian Hognestad har undersøkt karakteristiske trekk ved norsk mellomspråksintonasjon og skisserer noen mulige fagdidaktiske konsekvenser (Hognestad 2017). Han viser hvordan den faktiske intonasjonen hos S2-talere kan være og sammenlikner den med intonasjonen i norsk S1-tale. Han har tre S2-informanter: en 18 år gammel begynnerstudent i skandinavistikk fra Aserbajdsjan med azeri (et tyrkisk språk) som S1. Gutten har bare vært på et kort opphold i Norge. Den andre informanten er en voksen dame bosatt på Sørlandet. Hun har polsk som S1 og flere års botid i Norge. Den tredje informanten er en tysk student som har vært stipendiat i Trondheim, og som har botid i Norge på rundt tre år. Hognestads analyser bygger på opptak av norske tekster/setninger som to av de tre har lest inn. Analysen av den polske S1-talerens norsk er tatt fra et intervju med henne. Ingen av de tre S2-talerne skiller mellom de to toneaksentene, men hos kvinnen med polsk som $\mathrm{S} 1$ forekommer frekvente ord i hennes norske talespråk som ${ }^{2}$ laerer, ${ }^{2}$ klarte, ${ }^{2}$ vanskelig, med autentisk aksent 2-uttale. Hognestad tolker denne autensiteten som knyttet til enkeltord, leksikon, og ikke som en del av en fonologisk systemendring. Hognestads fokus i artikkelen er hvordan aksentfrasene realiseres i S2, og hvordan den intrikate sammenhengen mellom trykk og tone i norsk prosodi er, og hvordan den formidles (eller kanskje helst ikke formidles) av andrespråkslærere. Ved å bruke opptak av sin egen innlesning 
analysert i Praat demonstrerer han hvordan toneaksentene er med på å skape grunnfrekvenskurven, det vil si aksentfrasenes intonasjon (forstått innenfor et klassisk autosegmentalt rammeverk der de norske toneaksentene forstås som bygd opp av enten høye toner, H, eller lave toner, L. Disse kan kombineres på forskjellige måter som så kan fylle ulike typer markeringsfunksjoner som trykk, fokusprominens og APgrense). Ingen av de tre mellomspråkstalerne mestret norsk intonasjon fullt ut, men Hognestad mener at de alle tre har lagd seg et forenklet prosodisk system som i prinsippet er det samme for dem alle. De mestrer ikke toneaksentene og bruker i hovedsak bare én AP-melodi, en melodi som kan sies å være aksent 1melodien i det norske området de har bodd. De to første informantene markerer trykkstavelsene med høy tone, altså en HL-melodi som man kan si er en prosodisk grunnstruktur i mange språk. Den tyske studentens intonasjon beskrives derimot som en LH-melodi som Hognestad mener kan forstås som forenklet østnorsk, eller kanskje har base i talerens tyske førstespråk.

Steien (2014) studerer ordmelodier i spontan tale hos tolv S2-talere. Seks av dem har swahili som førstespråk, de seks andre har lingala. Swahili og lingala har typologisk ulike ordprosodiske systemer. Studiens mål er å se om ulikhetene mellom de to prosodiske systemene i talernes S1 har konsekvenser for hvorvidt de har tilegnet seg det norske leksikalske tonesystemet. Resultatene av studien viste ingen signifikante forskjeller mellom de to talergruppene. Det var imidlertid en klar tendens til at talerne i begge grupper overgeneraliserte aksent 2 .

Det finnes én undersøkelse av toneaksentene i norsk S2 som konkluderer med at flerspråklige S2talere av norsk i stor grad produserer autentiske norske toneaksenter (Steien og van Dommelen 2016). Forklaringen forfatterne gir på en slik mestring, er at det dreier seg om S2-talere som hadde utstrakt erfaring med å lære språk da de begynt å lære norsk. De var alle født inn i flerspråklige miljøer og hadde lært og brukt språk med typologisk ulike prosodiske systemer gjennom hele livet.

Kuronen (2015) har gjort en undersøkelse av hvordan finske S1-talere lærer seg toneaksentene i svensk gjennom formell undervisning og uten langt opphold i Sverige. Finsk har ingen tonal kontrast i trykksterk stavelse. Kuronen finner at av ni finske universitetsstudenter med «svenska som sitt huvud- eller biämne» lærer tre av studentene med finsk som S1 å mestre de to midtsvenske toneaksentene etter et seks ukers langt uttalekurs i svensk med fonetisk «inriktning». De individuelle forskjellene var store, og to av de finske studentene lærte seg ingen av de svenske toneaksentene. Kuronen finner heller ikke støtte for at den ene av de to svenske aksentene (accent 2) er vanskeligere å lære enn den andre: To av hans talere lærte seg aksent 1 , men ikke aksent 2; to andre lærte seg aksent 2, men ikke aksent 1.

\section{Østnorske toneaksenter}

Den kontrastive grunntonevariasjonen, f0, i norsk er avhengig av hovedtrykkstavelsene. Det er i de aksentuerte hovedtrykkstavelsene vi kan registrere den tydelige forskjellen i tonebevegelse i de to toneaksentene. Bitrykksstavelser genererer ingen toneendring slik at for eksempel sammensatte ord kan tilhøre én og samme AP, for eksempel ${ }^{1}$ dyrlege eller ${ }^{2}$ juleferie, hvor bitrykket ligger på første stavelse i det 
andre leddet i sammensetningen (-le- og -fe-). Aksentfrasen kan også begynne inne i et ord, falmilie(ferie). I mange språk har trykksterk stavelse høyere tone. Det gjelder for engelsk, tysk, fransk og italiensk (Ophaug 2010). I mange norske dialekter er det også slik, men i østnorsk som er en såkalt lavtonedialekt, beskrives de to toneaksentene fonologisk som LH (aksent 1) og HLH (aksent 2). I aksent 1 sammenfaller lav tone, L, med den trykksterke stavelsen, mens i aksent 2 er det den første høye tonen, H, som er inkludert i hovedtrykkstavelsen.

Jeg tar her utgangspunkt i beskrivelsen av de to østnorske toneaksentene hos Kristoffersen (2006), se figur 1. Kristoffersens prosodiske modell er utarbeidet innenfor et metrisk-autosegmentalt rammeverk (jf. Hognestads beskrivelse i foregående avsnitt; se også Husby \& Kløve 2001:94), det samme er modellen som presenteres for standardtysk intonasjon (figur 2). I tråd med Kristoffersens framstilling av tonekontrasten i østnorsk begynner også min analyse i trykklett stavelse før hovedtrykkstavelsen.

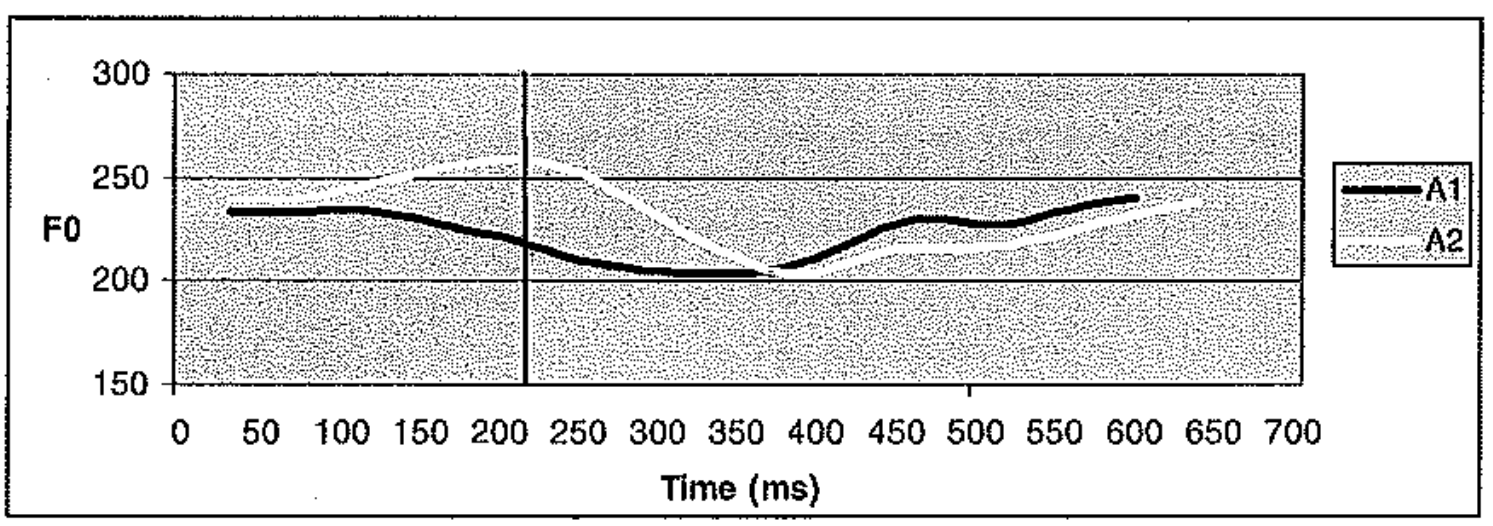

Figur 1: Stilisert framstilling av de to toneaksentene etter Kristoffersen (2006)

Den vertikale linjen i figur 1 viser den trykksterke vokalens begynnelse. De to aksentkurvene begynner i trykklett stavelse før den trykksterke stavelsen med et felles utgangspunkt. F0-kurven for aksent 2 (den lyse kurven) stiger mot sitt høyeste punkt nær begynnelsen av den trykksterke vokalen, mens en slik stigning ikke finner sted ved aksent 1 (den mørke kurven). Det laveste nivået for aksent 1-kurven sammenfaller med slutten av den trykksterke stavelsen. Dette går ikke klart fram av figuren, men det sies i artikkelen (Kristoffersen 2006:99). For aksent 2-kurven inntreffer det laveste nivået litt senere, i den trykklette stavelsen som følger etter den trykksterke stavelsen. Den fonologiske tolkningen av disse kurvene er HLH (Høy-Lav-Høy) for aksent 2 og LH (Lav-Høy) for aksent 1. Den første høye tonen (H) i aksent 2 og de siste høye tonene i begge toneaksentene sprer seg ikke over flere stavelser. I beskrivelsen av de to toneaksentene har de mellomliggende trykklette stavelser i østnorsk lav tone fram til nest siste stavelse hvor f0 stiger bratt mot siste H (Kristoffersen 2006:99-100). 


\section{Tone og trykk i standardtysk}

I en artikkel om et fonologisk system for framstilling av standardtysk intonasjon, GToBI (German Tones and Break Indices), beskriver artikkelforfatterne GToBI slik:

“... an annotation scheme for capturing aspects of the intonation of Standard German within the autosegmentalmetrical framework. We concentrate on the tonal part of the system, providing an inventory of commonly occurring contours, and discuss issues which are still controversial within the framework, such as leading tones and phrase accents" (Baumann, Grice og Benzmüller 2000).

\begin{tabular}{|c|c|c|c|c|}
\hline & GToBI & Schematic Contour & Context & Example \\
\hline \multirow[t]{2}{*}{ Fall } & \multirow[t]{2}{*}{$\begin{array}{c}\mathrm{H}^{*} \\
\mathrm{~L}-\%\end{array}$} & & Neutral statement & $\begin{array}{l}\text { Mein ZAHN tut WEH. } \\
\text { My tooth hurts. }\end{array}$ \\
\hline & & & $\begin{array}{c}\text { Neutral } \\
\text { W-question }\end{array}$ & $\begin{array}{c}\text { Wo hast du den WAgen } \\
\text { gePARKT? } \\
\text { Where did you park the car? }\end{array}$ \\
\hline & $\begin{array}{l}\mathrm{L}+\mathrm{H}^{*} \\
\mathrm{~L}-\%\end{array}$ & & $\begin{array}{l}\text { Contrastive } \\
\text { assertion }\end{array}$ & $\begin{array}{c}\text { Schon der VerSUCH ist } \\
\text { STRAFbar! } \\
\text { Even to attempt is an offence! }\end{array}$ \\
\hline
\end{tabular}

Figur 2: Stilisert framstilling av intonasjonen i standardtysk i tre typer kontekst etter Baumann, Grice \&

\section{Benzmüller (2000)}

Figur 2 er bare en del av et større skjema med mange ulike "Context", men den øverste skjematiske konturtonen her skal gi en fonologisk beskrivelse av tonegangen i "Context"-typene utsagnssetninger "Neutral statement” og spørsmål "Neutral W-question" som er de typene ytringer som er med i mitt materiale. Vi kan legge merke til at i skjemaet skilles det ikke mellom intonasjonen i de to ytringstypene. Forklaringen de gir på ulike linjer og bokstavtyper i skjemaet er som følger:

"Capitals in bold face indicate nuclear syllables, plain capitals postnuclear stresses. In the schematic contours, extra heavy lines represent accented syllables, heavy lines postnuclear stressed syllables (if available), and dotted lines the speaker's baseline."

Den tyske fonologiske beskrivelsen skiller seg fra beskrivelsen av de norske toneaksentene ved at det angis én intonasjonskurve og særlig tonebevegelsen etter aksentuert stavelse er ulik, mens begynnelsen og den aksentuerte stavelsen kan ligne østnorsk aksent 2-kontur. Samspillet mellom trykk og post-leksikalsk intonasjon er svært ulik i disse fonologiske beskrivelsene av de to standardvariantene av tysk og norsk. 


\section{Hypoteser basert på tidligere nevnte studier og figurer}

Den kanskje mest nærliggende hypotesen basert på en sammenlikning av figur 1 og 2 er at de tyske talerne ikke vil skille mellom de to norske toneaksentene. En annen hypotese som kan motiveres ut fra en slik metrisk-autosegmental tilnærming til tysk og norsk prosodi, er at de tyske studentene som uttaler østnorske aksent 1-ord, vil ha en høyere tone i den aksentuerte stavelsen enn de norske S1-talerne.

Lundemo (2003) framhever i en kontrastiv beskrivelse av norsk og tysk tonegang at det i tysk bare er betonte stavelser som kan være aksentuerte (i betydningen 'ha en høyere tone'), dessuten at tonem 1 i mange nordnorske dialekter kommer den tyske «Akzent» temmelig nær, det vil si høy tone i trykksterk stavelse.

En annen referanse til prosodien i nordnorske dialekter gir Hognestad (2017). Han viser til de områdene i Troms og Finnmark der dialektene ikke har toneaksentkontrast. Disse nordnorske dialektene har initialtrykk karakterisert ved høytone og fravær av tonelagsmotsetning. De prosodiske trekkene er blitt beskrevet som etnolektiske trekk med historisk opphav i møtet mellom nordsamisk eller kvensk og norsk. Hognestad mener at intonasjonen i disse nordnorske dialektene kan være sammenliknbar med intonasjonen som oppstår i dag hos S2-talere av norsk i møte med den komplekse norske intonasjonen (Hognestad 2017:82).

En empiri som støtter hypotesen om at de tyske studentene i min granskning ikke vil skille mellom de norske toneaksentene, er den før nevnte tyske stipendiaten i Trondheim (Hognestad 2017:78). Denne stipendiaten innleder alle APer med lav tone, slik at hans gjennomførte melodi er LH og ikke HL som vi kunne ha forventet.

\section{Mål, materiale og metode}

Hovedmålet med denne unders $\varnothing$ kelsen er å svare på følgende spørsmål:

1) Hva slags tonekonturer produserer de tyske S2-talerne i møte med (øst)norsk?

2) Hvilke aspekter ved østnorske toneaksenter skaper problemer for S2-talerne?

3) Er det forskjeller i realiseringen av de to toneaksentene hos S2-talerne?

Dessuten vil jeg kommentere spørsmålet om hvordan tonegangen hos de østnorske S1-talerne sammenfaller med den fonologiske beskrivelsen hos Kristoffersen (2006).

I unders $\varnothing$ kelsen av de to toneaksentene tar jeg utgangspunkt i trykklett stavelse før den aksentuerte stavelsen i tråd med framstillingen av den østnorske tonekontrasten hos Kristoffersen (2006), se figur 1. For å få tydeligere fram variasjonen i tonebevegelsen som er til stede også hos de norske S1-talerne, tar jeg med hele aksentfrasens kurve i deler av min analyse selv om hovedfokus er på bevegelsen i aksentuert trykksterk stavelse (eg. den trykksterke lange vokalen). Til den akustiske analysen har jeg brukt taleanalyseprogrammet Praat (Boersma \& Weenink 2016). Data er videre eksportert fra Praat til Excel hvor sammenlikninger og grafisk framstilling er gjort. 


\section{S1- og S2-deltakerne}

I alt 14 talere deltok i denne undersøkelsen. Sju utenlandske studenter på norskkurs ved UiO (trinn 3), fem kvinner og to menn. De sju hadde alle tysk som førstespråk og kom fra forskjellige deler av Tyskland: fra Oldenburg i nord til München og Sveits (nær den tyske grensen) i sør, fra Köln og Münster i vest til Berlin i $\emptyset$ st, eller fra mindre byer i nærheten av disse store byene. Studentene hadde en oppholdstid i Norge på mellom fire måneder og to og et halvt år. Opptakene ble gjort i april 2016. Da hadde alle de tyske S2-talerne gått minst tre måneder på norskkurs ved UiO. De tyske studentene var mellom 21 og 26 år da opptakene ble gjort. Alle de sju S2-talerne karakteriserte norskferdighetene sine som enten gode eller at de snakket norsk flytende.

De sju andre deltakerne hadde norsk (østnorsk) som S1, og kom fra Lillehammer i nord til Hurum i sør, fra Drammen i vest til Oslo i øst. De østnorske talerne var også fem kvinner og to menn. De norske S1talerne var alle ansatt som forskere/lærere ved ILN og ble rekruttert fra et mest mulig snevert $\varnothing$ stlandsområde. De norske førstespråkstalerne var mellom 28 og 70 år. De fleste av dem var vesentlig eldre enn de tyske studentene, men resultatene av denne undersøkelsen gir ikke noe klart bilde av om alder er relevant i forhold til for eksempel toneleie.

\section{Materiale, opptak og analyse}

Det innleste materialet består av åtte setninger valgt ut fra et større materiale på i alt 30. Fra de åtte setningene valgte jeg ut ti enkeltord, fem der ordet i østnorsk uttales med aksent 1 og fem der ordet uttales med aksent 2. Kun setninger der talerne aksentuerte samme hovedord ble valgt. (Egentlig omfatter analysen aksentfraser der de ti ordene er det trykksterke hovedordet i den aktuelle AP.) Man kan innvende mot innleste setninger at man får en "leseintonasjon" og ikke naturlig tale. Men ordene i setningene som ble lest inn, burde være velkjente for så langtkommende S2-studenter. Setningene i seg selv var enkle. De leste hver setning to ganger, innlesningene var stort sett identiske og feil som for eksempel forkorting av lang vokal ble gjentatt i innlesning nummer to. Hvilken innlesning som ble valgt, bestemte jeg etter å ha lyttet til begge opptakene og vurdert det akustiske bildet. Opptakene ble gjort med en digital lydopptaker på et kontor på Universitetet i Oslo. Innspillingene ble deretter analysert i signalanalyseprogrammet Praat. Data ble så eksportert fra Praat til Excel der videre sammenlikninger og grafisk framstilling ble gjort. Alle målinger er gjort med 15 ms intervall (ca 70 målepunkter pr sekund).

De utvalgte ordene var typiske aksent 1- og aksent 2-ord: Bestemt form entall av enstavelsesord representerer tonegangen i aksent 1 (f.eks. bilen), og bestemt form eller flertall av adjektiv representerer aksent 2 (f.eks. dyre). Til sammen ble 140 (138, se nedenfor) aksentfraser analysert. De åtte utvalgte setningene var følgende ${ }^{1}$ :

\footnotetext{
${ }^{1}$ De analyserte ordene er understreket her, men de var ikke understreket da talerne leste setningene.
} 
1 Hun sa det var bilen vår.

2 Hvordan var været i går?

3 De spiste maten $\sin$.

4 Hun snakket om huset da vi traff henne.

5 Det sure barnet hylte høyt.

6 Hun kjører gjerne pene biler.

7 Hun mistet den fine pennen.

8 De dyre mattene var gule og svarte.

\section{Resultater}

\section{Uttale av aksent 1 hos norske S1-talere}

De fem ordene som inngikk i granskningen av aksent 1 var bilen (Hun sa det var bilen vår), barnet (Det sure barnet hylte høyt), huset (Hun snakket om huset da vi traff henne), maten (De spiste maten sin) og varet (Hvordan var været i går?). Hos de norske talerne har jeg til sammen analysert 35 ord (aksentfraser) med aksent 1 ( 7 informanter $\times 5$ ord). Alle talerne har fătt en kode slik at 8 kno betyr at taler nummer 8 er kvinne (k) og norsk (no). For eksempel 6 mty betyr at taler nummer 6 er mann (m) og tysk (ty).

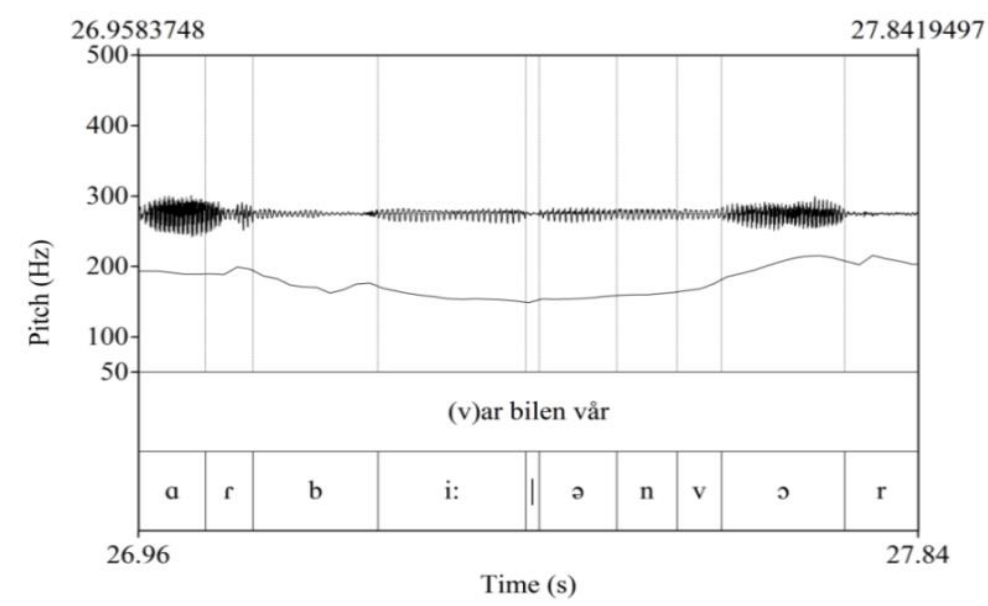

Figur 3: Aksent 1 i frasen «(v)ar bilen vår», S1-taleren 8 k(vinne) no(rsk)

Denne norske S1-taleren, 8 kno (figur 3), inkluderer siste ord i setningen, «vår», i aksentfrasen. Vi ser at kurvens laveste område er siste del av den trykksterke vokalen /i:/, mens kurven stiger brattest i siste stavelse som også er setningsslutt. Den lave tonen i /i:/ strekker seg over i siste trykklette stavelse i «bilen». 


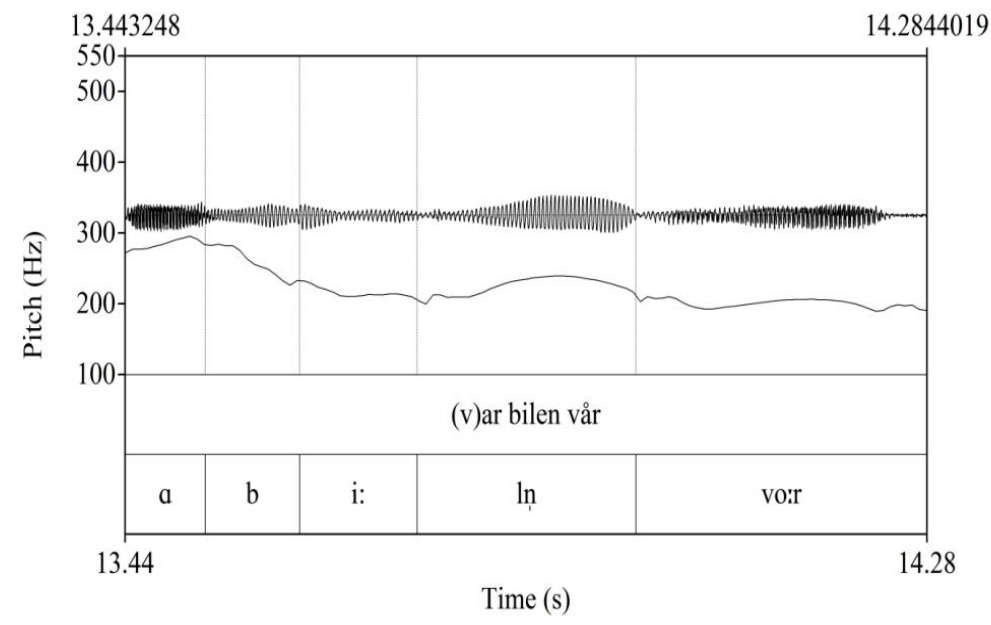

Figur 4: Aksent 1 i frasene «(v)ar bilen» og «vår», S1-taleren 11 k(vinne) no(rsk)

Hos S1-taleren 11 kno (figur 4) har vi to aksentfraser: «(var) bilen» og «vår». Hun skiller seg ut blant de norske kvinnelige S1-talerne ved at toneleiet (hertz-verdiene, den vertikale aksen) er høyere enn hos de andre, men f0-kurvens bevegelse i den første AP følger A1-konturen i figur 1 med jevn lav tone i siste del av den lange trykksterke vokalen /i:/ og stigning i etterfølgende trykklette stavelse. Den siste AP, «vår», viser jevn eller litt fallende intonasjon ved setningsslutt.

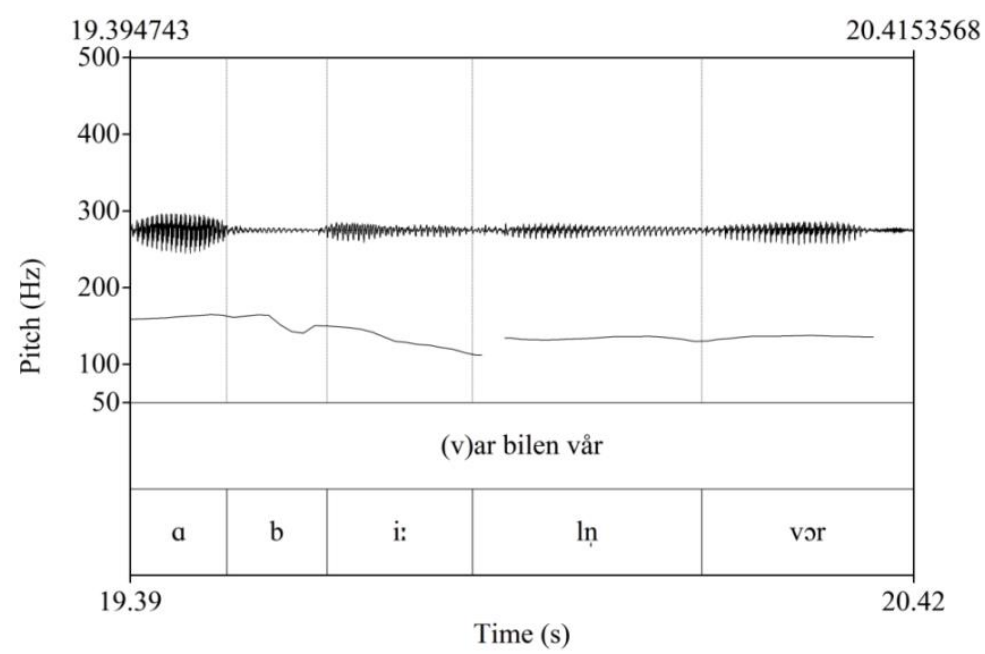

Figur 5: Aksent 1 i frasen «(v)ar bilen vår», S1-taler 12 k(vinne) no(rsk)

Også S1-taleren 12 kno har den laveste tonen på slutten av trykksterk vokal, /i:/. Tonen i de etterfølgende trykklette stavelsene innenfor samme AP, som også er setningsslutt, er noe høyere, men jevn. 


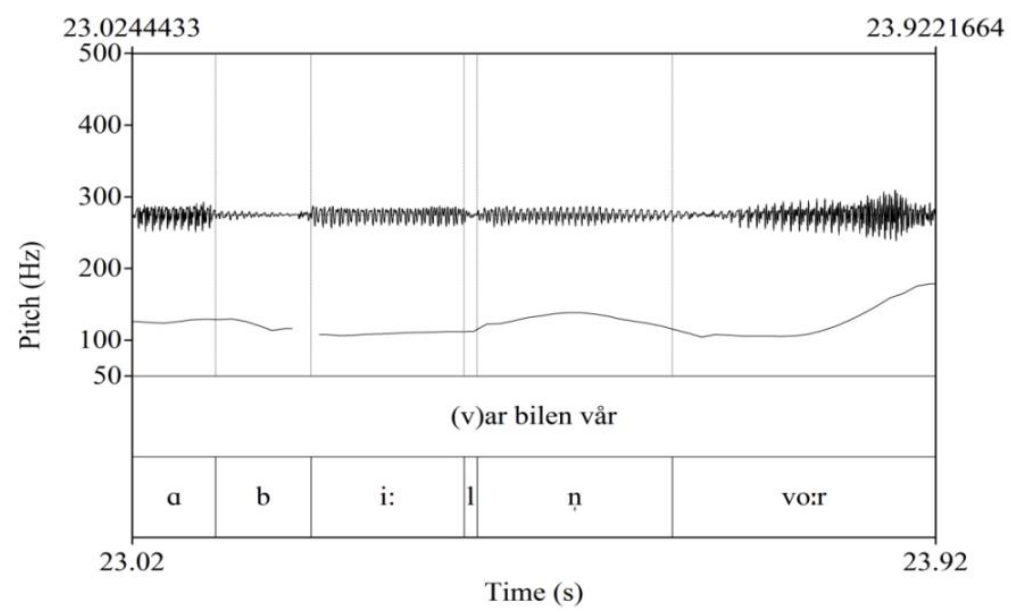

Figur 6: Aksent 1 i frasene «(v)ar bilen» og «vår», S1-taler 14 m(ann) no(rsk)

Hos denne ene av de to norske mannlige S1-talerne, 14 mno (figur 6), ser vi jevn lav tone i den lange, trykksterke i-en, stabiliseringen av den lave tonen starter litt tidligere i stavelsen enn hos de tre foregående norske informantene. Frekvensverdiene er lavere, typiske for en mannsstemme. Vi ser at overgangen mellom de to aksentfrasene markeres med fall i tonekurven hos 11 kno og 14 mno (figur 4 og 6), og de har begge tydelig stigning på siste stavelse $\mathrm{i}$ «bilen». Bare S1-talerne 8 og 14 har stigende tone mot setningsslutt (figur 3 og 6). Hos 8 kno (figur 3) hvor frasen «(var) bilen vår» omfattes av én AP, har tonen svak stigning på den siste stavelsen $\mathrm{i}$ «bilen», men stiger brattere på det trykklette «vår» ved setningsslutt. Aksent 1kurven i figur 3 eksemplifiserer nærmest den fonologiske beskrivelsen av aksent 1 i figur 1! Hos alle disse fire norske S1-talerne er tonen i trykklett stavelse, /a/, før aksentfrasens begynnelse høyere enn i den trykksterke vokalen /i:/ i neste stavelse, og aksentfrasens laveste område er i den trykksterke lange i-lyden. I forhold til A1-konturen i figur 1 er det stor grad av overensstemmelse, men den bratte stigningen på slutten av aksentfrasen modereres av setningsintonasjonen, særlig tydelig hos informant 12. Tonehøyden i figur 1 er på cirka 200 hertz $(\mathrm{Hz})$ ved slutten av trykksterk vokal. Det er bare én av de norske S1-talerne, 11 kno, som har så høy tone som laveste nivå ved aksent 1-ord, men vi må være klar over at det er den relative høyden som er relevant her. 


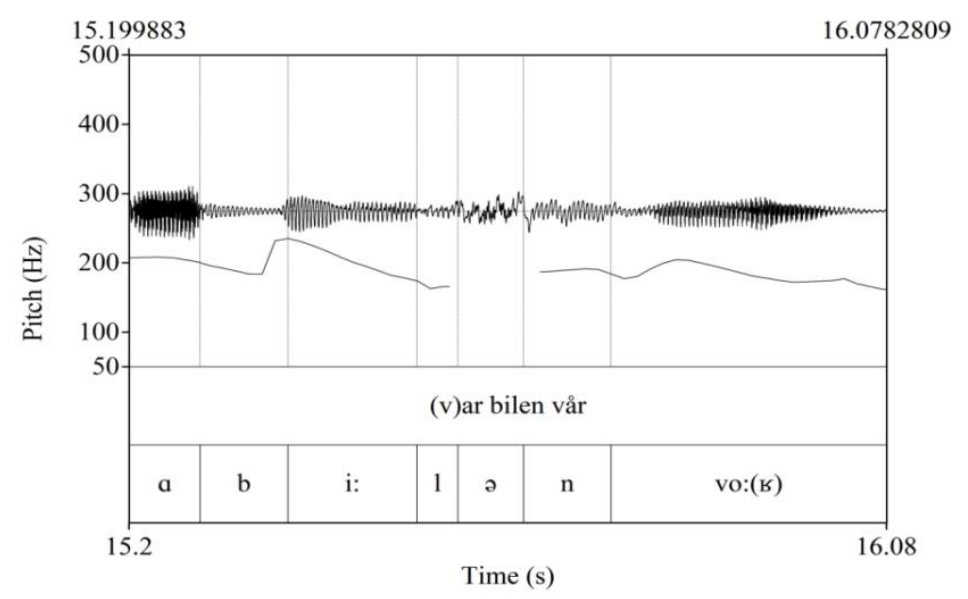

Figur 7: Aksent 1 i frasene «(v)ar bilen» og «vår», S2-taler 1 k(vinne) ty(sk)

Denne tyske studenten deler også ytringen inn i to aksentfraser. Tonegangen skiller seg fra de norske S1talerne ved at det skjer en stigning mot begynnelsen av /i:/ og et ganske bratt fall i den trykksterke vokalen. Kurvens laveste område kommer i stavelsen etter /i:/. Denne kurven likner mer på beskrivelsen av en østnorsk aksent 2-kurve (figur 1) og på den standardtyske kurven i figur 2.

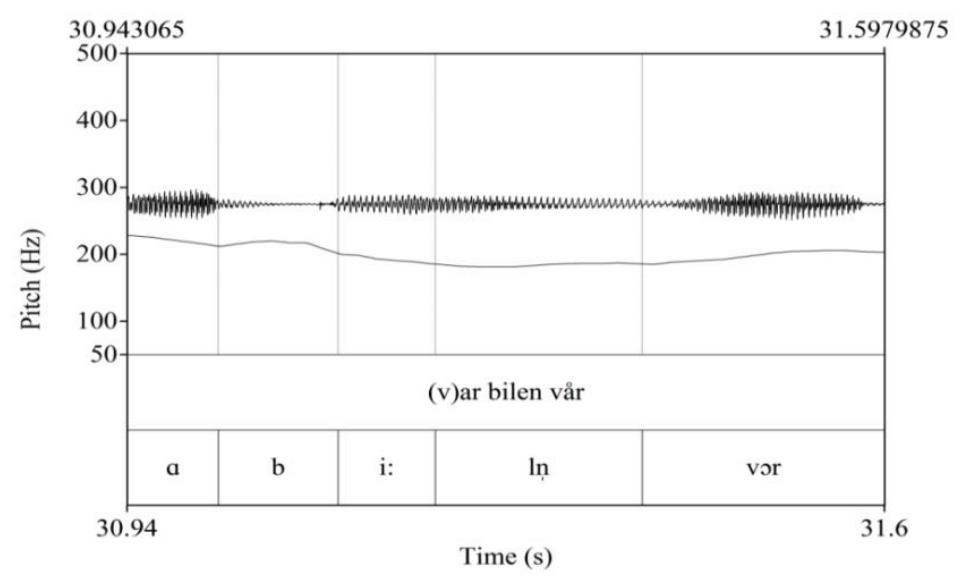

Figur 8: Aksent 1 i frasen «(v)ar bilen vår», S2-taler 3 k(vinne) ty(sk)

S2-taleren 3 kty (figur 8) har en tonegang som er mer lik den norske, men aksentfrasens laveste område ligger i trykklett stavelse etter /i:/. Hun har likevel et betydelig fall i /i:/ selv om det ikke er like åpenbart som hos foregående S2-taler (1 kty). 


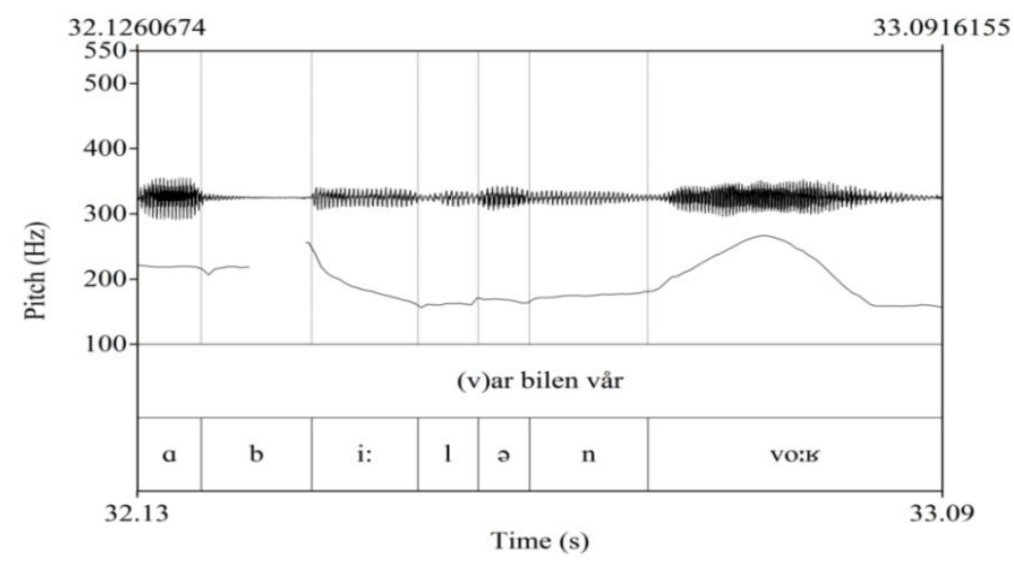

Figur 9: Aksent 1 i frasene «(v)ar bilen» og «vår», S2-taler 5 k(vinne) ty(sk)

Tonegangen hos 5 kty (figur 9) minner om den første tyske S2-taleren, 1 kty (figur 7), med sterkt fallende tone i /i:/ og en høyere tone ved begynnelsen av den trykksterke vokalen. Figurene 7, 8 og 9 viser uttalen til tre av de tyske kvinnelige S2-talerne. Frekvensen i utgangstonen i trykklett (v)a(r) er høyere enn $200 \mathrm{~Hz}$ hos alle tre. Hos disse tre S2-talerne er aksentfrasens laveste område i trykklett stavelse etter /i:/.

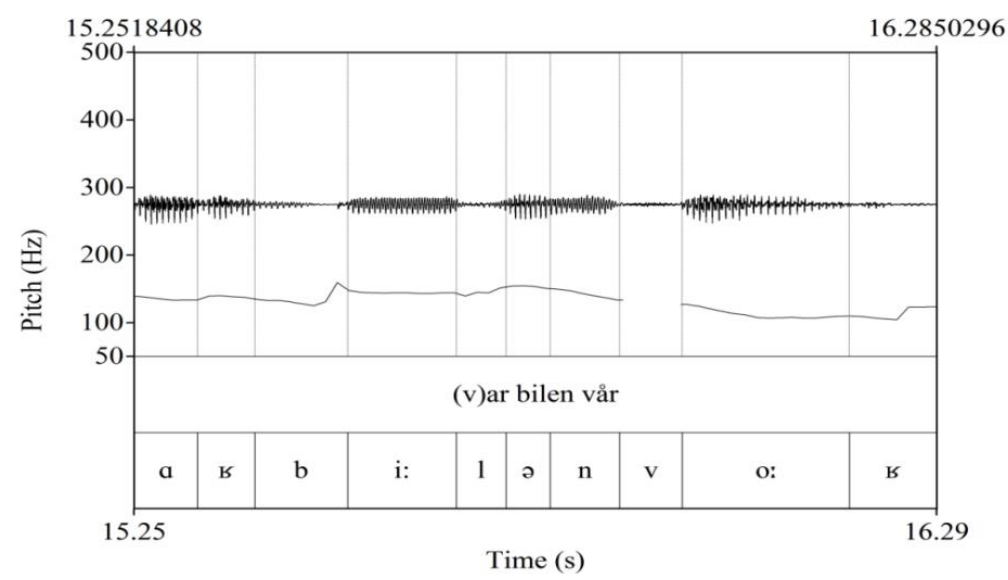

Figur 10: Aksent 1 i frasene «(v)ar bilen» og «vår», S2-taler 7 m(ann) ty(sk)

Hos denne mannlige tyske taleren, 7 mty (figur 10), er frekvensverdiene lave (som hos den norske mannlige taleren, figur 6). Vi kan legge merke til at tonen i den lange vokalen /i:/ ligger litt høyere enn utgangstonen i siste stavelse i foregående AP (i motsetning til hos informant 3 kty), og at /i:/ har en jevn tone (til forskjell fra informantene 1 kty og 5 kty). Den jevne tonen i den aksentuerte vokalen /i:/ er litt høyere enn den avsluttende tonen i foregående AP. I de følgende figurene kan vi se tonegangen i den lange aksentuerte vokalen /i:/ i ordet bilen (figur $11 \mathrm{a} \mathrm{og} \mathrm{b)} \mathrm{og} \mathrm{i} \mathrm{frasen(e)} \mathrm{«(v)ar} \mathrm{bilen} \mathrm{vår»} \mathrm{(figur} 12 \mathrm{a} \mathrm{og} \mathrm{b)} \mathrm{hos} \mathrm{de} \mathrm{sju} \mathrm{tyske}$ S2-talerne og de sju norske S1-talerne: 

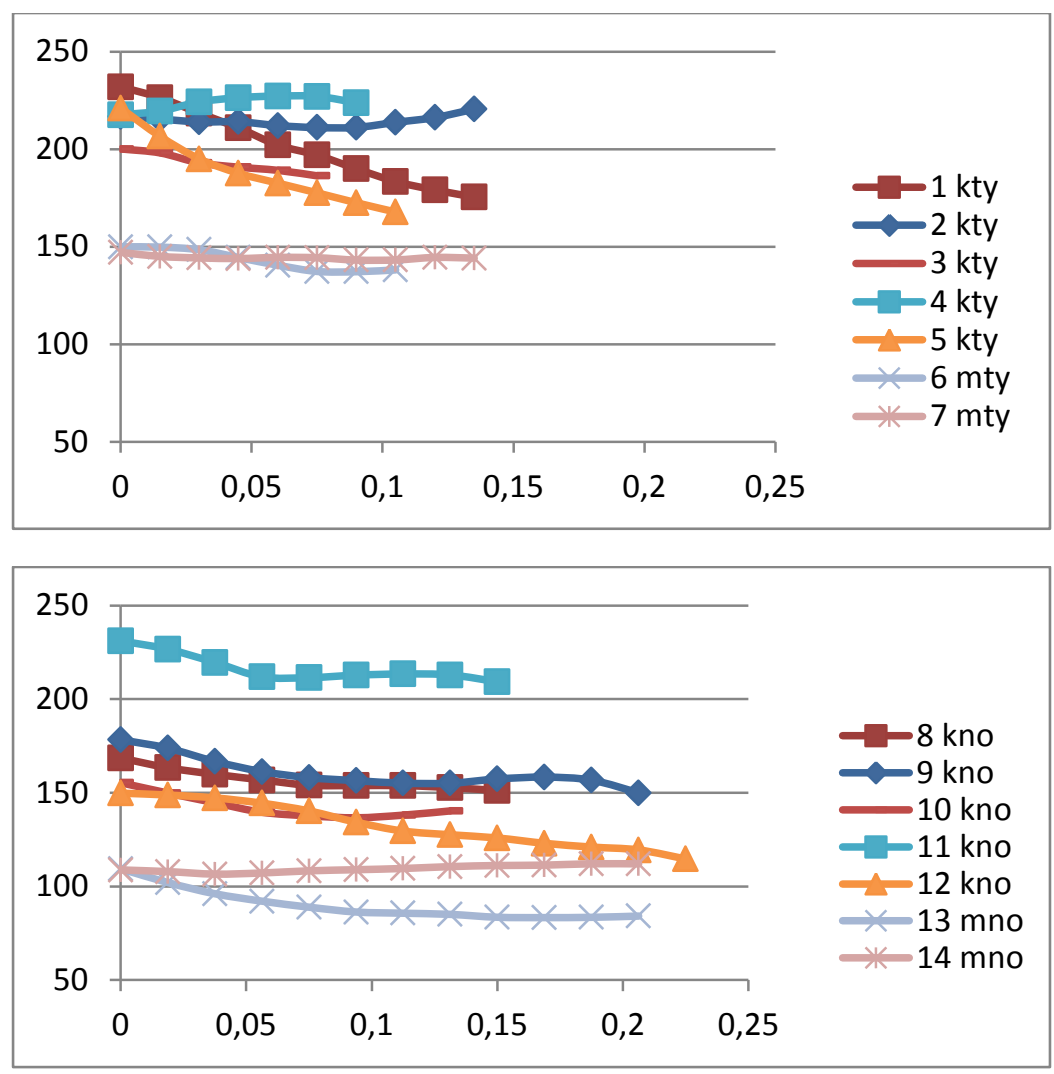

11 a) lang vokal $/ i: / i \ll$ bilen» - tysk

11 b) lang vokal $/ i: / i$ «bilen» - norsk

Figur 11 a) og b): Lang trykksterk vokal hos de tyske S2- og de norske S1-talerne ved aksent 1-ordet «bilen»
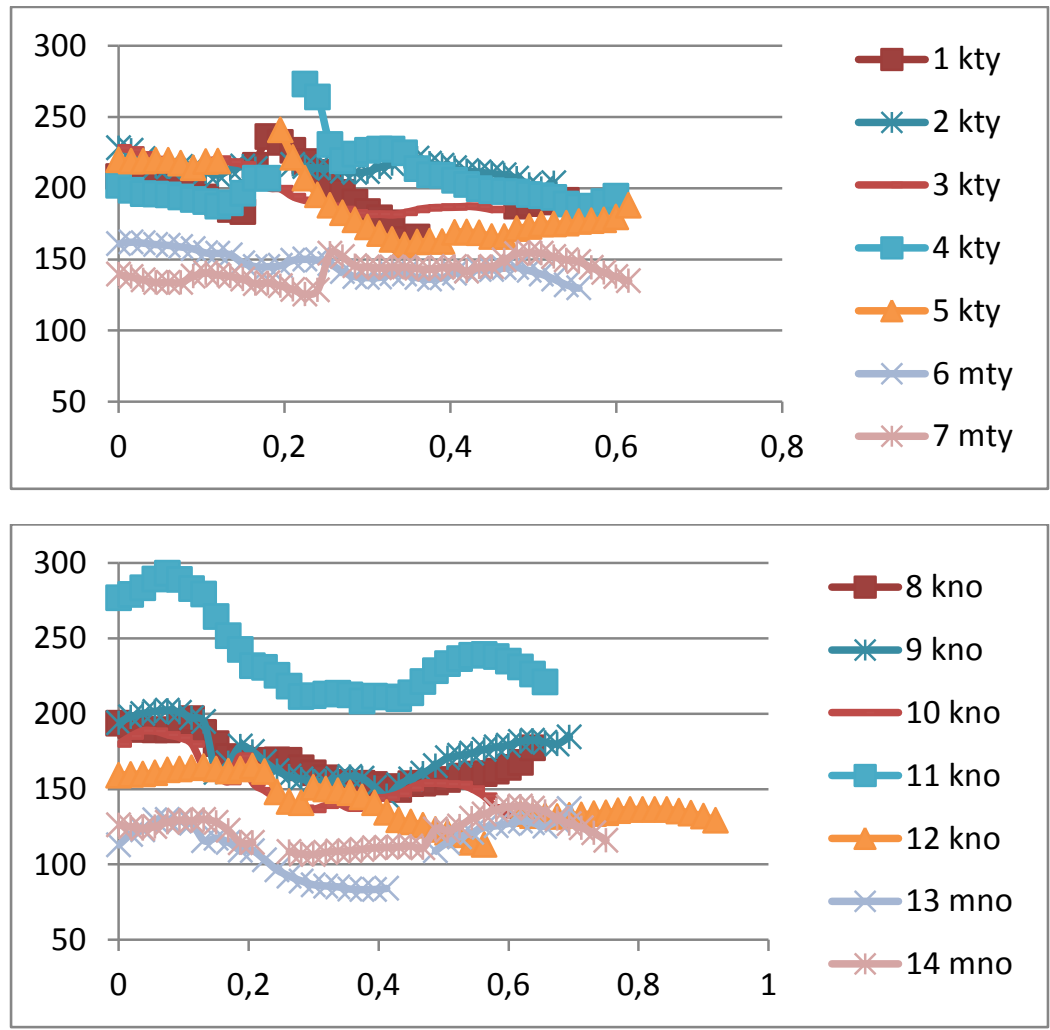

12 a) frasen $(e)$ «(v)ar bilen vår»-tysk

12 b) frasen(e) «(v)ar bilen vår» - norsk

Figur 12 a) og b): Aksentfraser hos de tyske S2- og de norske S1-talerne i frasen(e) «(v)ar bilen vår» 
Den ulike formen på aksentfrasene for både de tyske og de norske talerne i figur 12 a) og b) skyldes delvis ulik sluttintonasjon og delvis at f0-kurvene representerer både en og to aksentfraser. Vokalkurvene for /i:/ hos de norske informantene har lavere nivå mot slutten av vokalen enn i begynnelsen (unntatt hos informant 14 som har en liten stigning, fallet i aksent 1-kurven kommer litt tidligere i stavelsen hos ham enn hos de andre norske informantene). Vokalkurvene for de norske er i overensstemmelse med modellen til Kristoffersen (figur 1) ved at de gjennomgående har et svakt fall fra vokalens begynnelse og til dens slutt, og at utgangstonen, «a», i trykklett vokal før aksentfrasens begynnelse hos alle de norske informantene har en høyere tone enn tonen i vokalens begynnelse (se også tabell 1). Hos de tyske studentene er både det høyeste og det laveste nivået for f0-kurven i aksentuert vokal høyere på frekvensskalaen når man sammenlikner med talere av samme kjønn (unntatt hvis vi sammenlikner med førstespråkstaleren 11 kno). Hos informant 11 kno har kurven for øvrig et forløp som likner de andre norske informantene slik at det relative forløpet av tonekurvene er ganske likt. Hos de tyske informantene er utgangstonen i trykklett vokal, «a», før aksentfrasens begynnelse lavere enn tonen i den trykksterke vokalens begynnelse hos fem av de sju tyske informantene, S2-talerne 3 kty og 6 mty har noe høyere tone i «a» (se tabell 1). Vi ser også av tabell 1 at frekvensverdiene ved slutten av trykksterk vokal er lavere enn i etterfølgende trykklette vokal hos alle de norske informantene, mens den varierer hos de tyske. Det betyr at aksent 1-kurvens laveste punkt hos de tyske studentene også ligger i etterfølgende trykklette stavelse. Nivåforskjellen mellom begynnelse og slutt av den lange trykksterke vokalen /i:/ er svært stor hos to av de tyske studentene (1 kty og 5 kty), se Forskj(ellen) i tabell 1. Hos de andre tyske studentene er tonebevegelsen i /i:/ jevnere, men med en høyere tone enn hos seks av de sju norske førstespråkstalerne. Vi kan også legge merke til at vokalvarigheten av /i:/ i ordet «bilen» gjennomgående er kortere hos de tyske studentene enn hos de norske S1-talerne (figur 11a og b). De tyske S2-talerne 3 kty og 4 kty produserer en svært kort /i:/ som i målspråksfonologien er lang. Informant 3 kty har også en fallende tone i den trykksterke vokalen, men det kommer ikke tydelig fram fordi vokalen er så kort. Etter forløpet av vokalkurvene i /i:/ kan vi gjøre en foreløpig inndeling av de tyske informantene: S2-talerne 1, 3 og 5 faller i én gruppe med et ganske sterkt fall i tonekurven, mens de fire andre tyske S2-talerne, 2, 4, 6 og 7 kommer i en annen gruppe fordi de har en jevn, høy (i forhold til de norske) tone i den trykksterke vokalen i aksent 1-ordet bilen. Tabell 1 dokumenterer det vi kan observere fra de foregående figurene. 
Tabell 1: f0 ved begynnelse, a, og slutt, $n$, i frasen «(v)ar bilen» hos de tyske S2- og de norske S1-talerne

(Her er «a» målt omtrent midt i den trykklette vokalen før aksentfrasens begynnelse; «a» er det felles utgangspunktet for de to aksentkurvene (jf. figur 1); «n» er målt i siste stavelse $\mathrm{i}$ «bilen» omtrent midt i stavelsen. Variasjonen $\mathrm{i}$ «n» kan knyttes til ulik setningsintonasjon (ulik inndeling i APer) både hos de tyske og norske informantene. «Forskj.»er frekvensforskjellen mellom begynnelse og slutt av den trykksterke vokalen /i:/.)

\begin{tabular}{|l|c|c|c|c|c|c|l|c|c|c|c|c|}
\hline $\begin{array}{l}\text { Inf. } \\
\text { tysk }\end{array}$ & $\mathbf{a}$ & $\begin{array}{l}\text { Vokal } \\
\text { start }\end{array}$ & $\begin{array}{l}\text { Vokal } \\
\text { slutt }\end{array}$ & $\mathbf{n}$ & Forskj. & & $\begin{array}{l}\text { Inf. } \\
\text { norsk }\end{array}$ & $\mathbf{a}$ & $\begin{array}{l}\text { Vokal } \\
\text { start }\end{array}$ & $\begin{array}{l}\text { Vokal } \\
\text { slutt }\end{array}$ & $\mathbf{n}$ & Forskj. \\
\hline 1 kty & $208 \mathrm{~Hz}$ & $232 \mathrm{~Hz}$ & $175 \mathrm{~Hz}$ & $187 \mathrm{~Hz}$ & $56 \mathrm{~Hz}$ & $8 \mathrm{kno}$ & $189 \mathrm{~Hz}$ & $169 \mathrm{~Hz}$ & $152 \mathrm{~Hz}$ & $155 \mathrm{~Hz}$ & $17 \mathrm{~Hz}$ \\
\hline $2 \mathrm{kty}$ & $215 \mathrm{~Hz}$ & $217 \mathrm{~Hz}$ & $221 \mathrm{~Hz}$ & $211 \mathrm{~Hz}$ & $-4 \mathrm{~Hz}$ & $9 \mathrm{kno}$ & $202 \mathrm{~Hz}$ & $178 \mathrm{~Hz}$ & $151 \mathrm{~Hz}$ & $171 \mathrm{~Hz}$ & $27 \mathrm{~Hz}$ \\
\hline $3 \mathrm{kty}$ & $220 \mathrm{~Hz}$ & $200 \mathrm{~Hz}$ & $185 \mathrm{~Hz}$ & $186 \mathrm{~Hz}$ & $15 \mathrm{~Hz}$ & $10 \mathrm{kno}$ & $188 \mathrm{~Hz}$ & $154 \mathrm{~Hz}$ & $140 \mathrm{~Hz}$ & $147 \mathrm{~Hz}$ & $14 \mathrm{~Hz}$ \\
\hline $4 \mathrm{kty}$ & $196 \mathrm{~Hz}$ & $230 \mathrm{~Hz}$ & $224 \mathrm{~Hz}$ & $197 \mathrm{~Hz}$ & $6 \mathrm{~Hz}$ & $11 \mathrm{kno}$ & $289 \mathrm{~Hz}$ & $232 \mathrm{~Hz}$ & $208 \mathrm{~Hz}$ & $221 \mathrm{~Hz}$ & $23 \mathrm{~Hz}$ \\
\hline $5 \mathrm{kty}$ & $219 \mathrm{~Hz}$ & $221 \mathrm{~Hz}$ & $168 \mathrm{~Hz}$ & $169 \mathrm{~Hz}$ & $53 \mathrm{~Hz}$ & $12 \mathrm{kno}$ & $163 \mathrm{~Hz}$ & $150 \mathrm{~Hz}$ & $115 \mathrm{~Hz}$ & $132 \mathrm{~Hz}$ & $35 \mathrm{~Hz}$ \\
\hline $6 \mathrm{mty}$ & $160 \mathrm{~Hz}$ & $150 \mathrm{~Hz}$ & $139 \mathrm{~Hz}$ & $143 \mathrm{~Hz}$ & $11 \mathrm{~Hz}$ & $13 \mathrm{mno}$ & $129 \mathrm{~Hz}$ & $109 \mathrm{~Hz}$ & $84 \mathrm{~Hz}$ & $126 \mathrm{~Hz}$ & $25 \mathrm{~Hz}$ \\
\hline $7 \mathrm{mty}$ & $134 \mathrm{~Hz}$ & $152 \mathrm{~Hz}$ & $145 \mathrm{~Hz}$ & $154 \mathrm{~Hz}$ & $7 \mathrm{~Hz}$ & $14 \mathrm{mno}$ & $128 \mathrm{~Hz}$ & $108 \mathrm{~Hz}$ & $112 \mathrm{~Hz}$ & $138 \mathrm{~Hz}$ & $-4 \mathrm{~Hz}$ \\
\hline
\end{tabular}

Hvis vi studerer tonebevegelsen i de andre aksent 1-ordene (huset, barnet, maten, varet), finner vi individuelle mønstre som gjentar seg med mindre variasjoner både hos de tyske S2- og de norske S1- talerne:
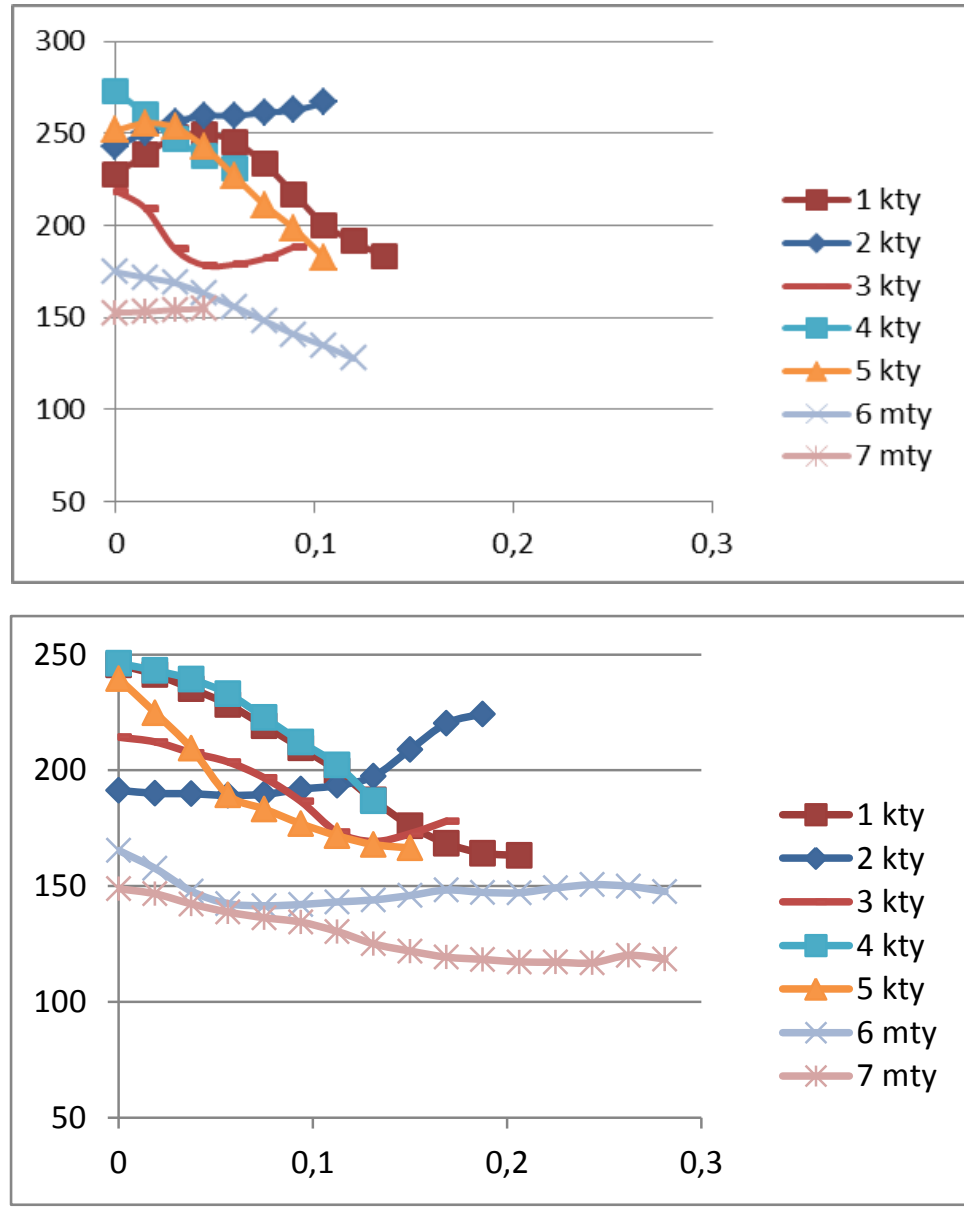

13 a) «huset», lang vokal/u./ - tysk

13 b) «barnet», lang vokal /a:/ - tysk 

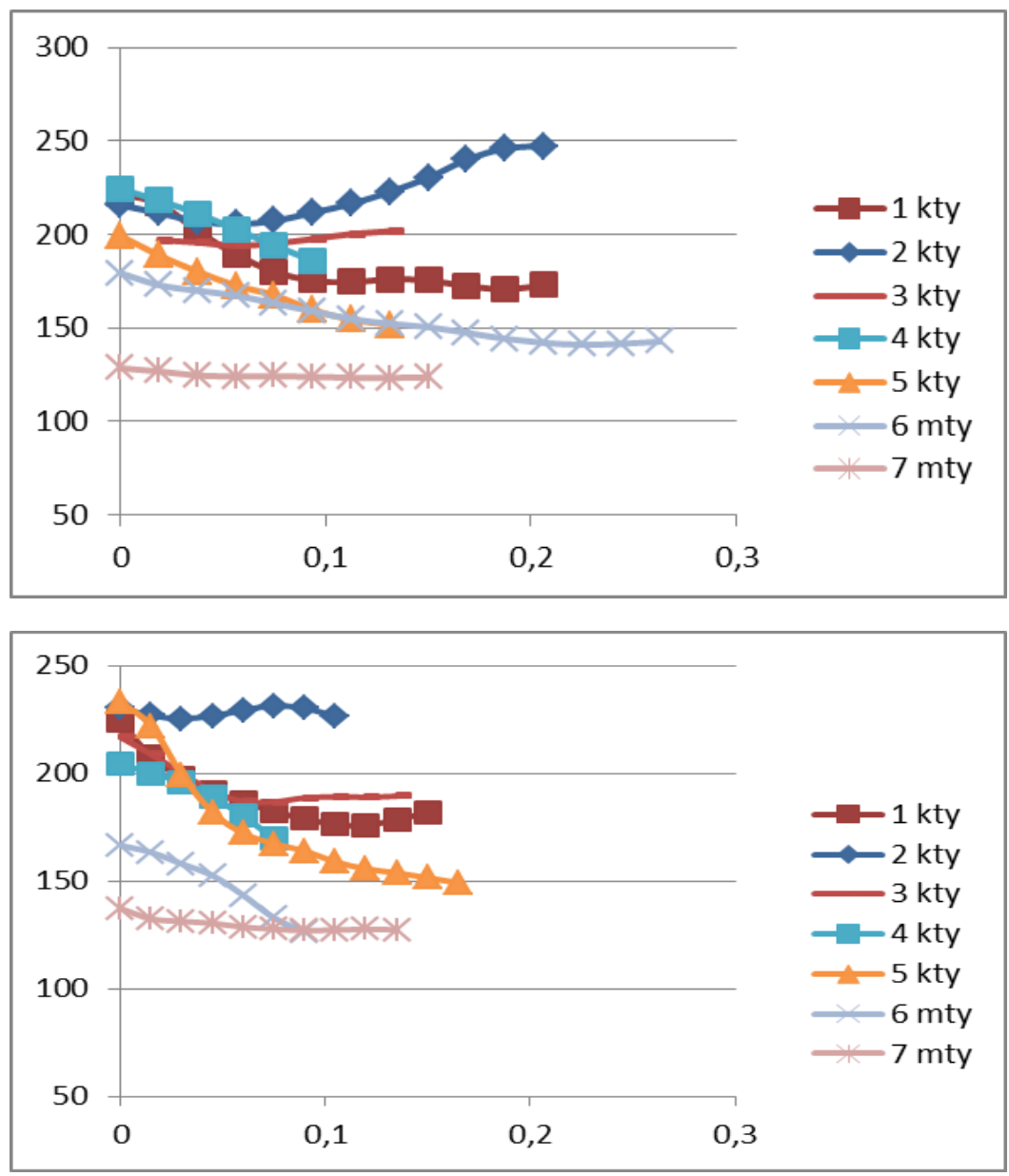

13 c) «varet», lang vokal /a:/ - tysk

$13 d) \ll m a t e n »$, lang vokal /a:/ - tysk

Figur 13 a), b), c) og d): tonegangen i de lange vokalene /u:/, /a:/og /ae:/i ordene "huset", "barnet", "varet" og "maten" hos de tyske S2-talerne

I framstillingen i figur 13 av de fire vokalene uttalt av de sju tyske S2-talerne ser vi at talerne 1 kty og 5 kty har et stabilt, bratt fall i alle vokaluttalene. Informant 3 har også et fall ved /u:/ og /a:/, men ikke ved /æ:/. Hun har en særegen kurve som stiger et stykke inn i vokalen. Taler 4 kty har også en fallende tone i disse fire ordene i motsetning til /i:/ i «bilen»; 4 kty kommer derfor i gruppe med 1 kty og 5 kty etter disse fire siste vokalframstillingene, men 4 kty har kortest, stabil vokalvarighet, betydelig kortere enn de seks andre tyske talerne. Den mannlige S2-taleren 6 mty er mer ustabil både når det gjelder vokalvarighet og forløpet av kurven, noe som også gjelder 7 mty. Den kvinnelige S2-taleren 2 kty skiller seg ut ved å ha en jevn og etter hvert stigende kurve i alle de fem undersøkte lange vokalene. Vi ser også av tabell 2 at hun har en negativ frekvensforskjell mellom begynnelse og slutt av den trykksterke vokalen. Informantene 1, 3 og 5 kommer fra nord eller nordøst i Tyskland. De fire andre tyske informantene er fra sør eller vest.

I de følgende figurene kan vi se en framstilling av de samme fire vokalene hos de sju norske S1talerne: 

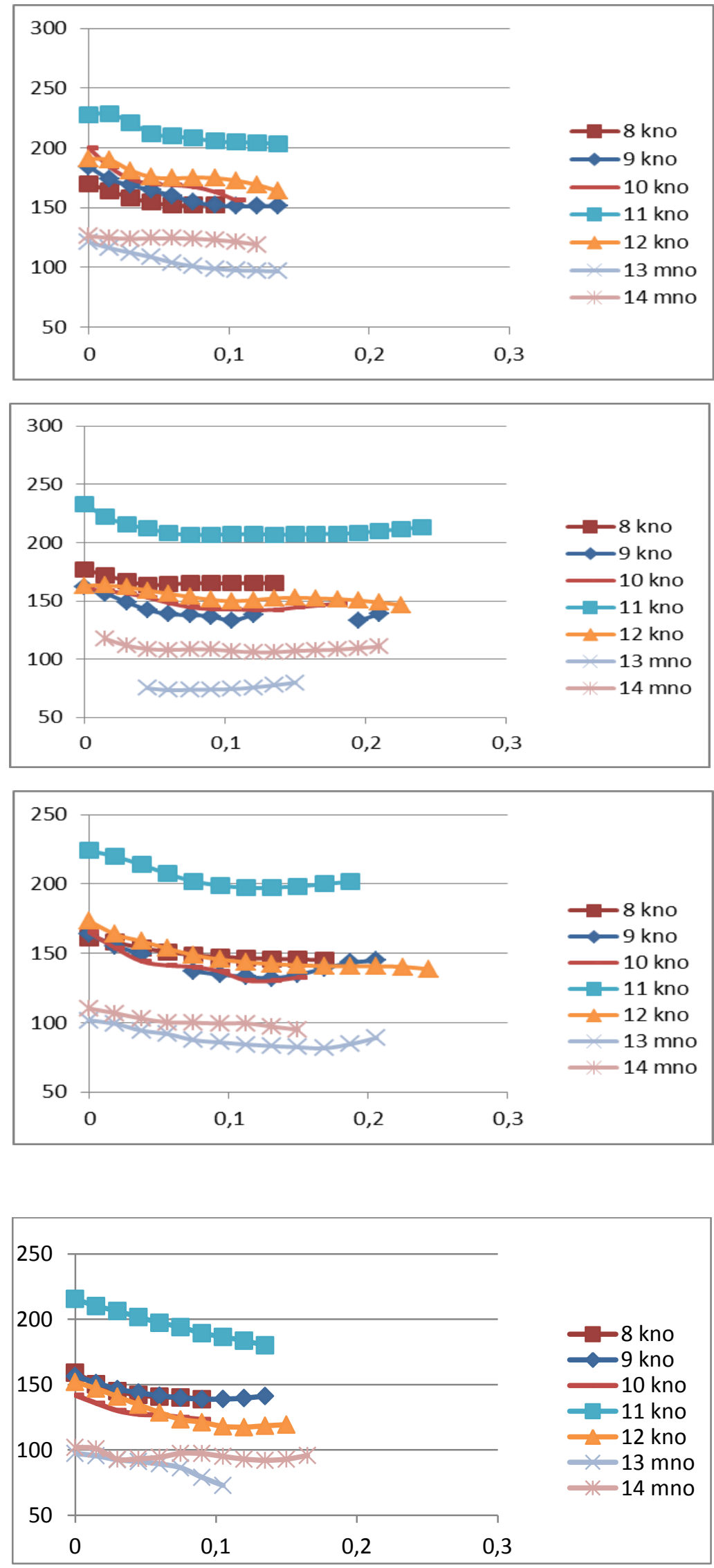

14 a) «huset», lang vokal/u:/ - norsk

14 b) «barnet», lang vokal /a:/ - norsk

14 c) «varet», lang vokal /ae:/ - norsk

Figur 14 a), b), c) og d): tonegangen i de lange vokalene /u:/, /a:/og /ae:/i ordene "huset», «barnet», "vaeret» og «maten» hos de norske førstespråkstalerne 
Selv om det også blant de norske S1-talerne er noe variasjon når det gjelder vokalvarighet og form på kurven, ser vi et gjentakende mønster med svakt fallende kurver hos alle sju. De to mannlige norske informantene har kurver som starter rundt 100 hertz eller litt høyere, fire av de fem kvinnelige norske informantene har vokalbegynnelse mellom 160 og $170 \mathrm{~Hz}$, mens informant 11 som er en av de eldste norske informantene, starter vokalkurven rundt $225 \mathrm{~Hz}$ (jf. tabell 2).

Tabell 2: Gjennomsnittsverdier for f0 ved begynnelse og slutt av trykksterk vokal i de fem aksent 1-ordene «bilen», «huset», «barnet», «varet» og «maten» hos de tyske og norske informantene (Her er «a» målt i midten av trykklett vokal før aksentfrasens begynnelse, og «n» midt i stavelsen etter den trykksterke vokalen. «Forskj.» er forskjellen $\mathrm{i}$ frekvens mellom begynnelse og slutt av de trykksterke vokalene /i:/, /u:/, /a:/ og /æ:/.)

\begin{tabular}{|l|c|c|c|c|c|c|c|c|c|c|c|}
\hline $\begin{array}{l}\text { Inf. } \\
\text { tysk }\end{array}$ & a & $\begin{array}{l}\text { Vokal } \\
\text { start }\end{array}$ & $\begin{array}{l}\text { Vokal } \\
\text { slutt }\end{array}$ & $\mathbf{n}$ & Forskj. & $\begin{array}{l}\text { Inf. } \\
\text { norsk }\end{array}$ & a & $\begin{array}{l}\text { Vokal } \\
\text { start }\end{array}$ & $\begin{array}{l}\text { Vokal } \\
\text { slutt }\end{array}$ & n & Forskj. \\
\hline 1 kty & $251 \mathrm{~Hz}$ & $231 \mathrm{~Hz}$ & $172 \mathrm{~Hz}$ & $200 \mathrm{~Hz}$ & $59 \mathrm{~Hz}$ & $8 \mathrm{kno}$ & $178 \mathrm{~Hz}$ & $167 \mathrm{~Hz}$ & $152 \mathrm{~Hz}$ & $196 \mathrm{~Hz}$ & $16 \mathrm{~Hz}$ \\
\hline $2 \mathrm{kty}$ & $228 \mathrm{~Hz}$ & $218 \mathrm{~Hz}$ & $237 \mathrm{~Hz}$ & $237 \mathrm{~Hz}$ & $-19 \mathrm{~Hz}$ & $9 \mathrm{kno}$ & $199 \mathrm{~Hz}$ & $171 \mathrm{~Hz}$ & $145 \mathrm{~Hz}$ & $183 \mathrm{~Hz}$ & $25 \mathrm{~Hz}$ \\
\hline $3 \mathrm{kty}$ & $224 \mathrm{~Hz}$ & $210 \mathrm{~Hz}$ & $189 \mathrm{~Hz}$ & $202 \mathrm{~Hz}$ & $21 \mathrm{~Hz}$ & $10 \mathrm{kno}$ & $196 \mathrm{~Hz}$ & $161 \mathrm{~Hz}$ & $140 \mathrm{~Hz}$ & $167 \mathrm{~Hz}$ & $21 \mathrm{~Hz}$ \\
\hline $4 \mathrm{kty}$ & $214 \mathrm{~Hz}$ & $236 \mathrm{~Hz}$ & $201 \mathrm{~Hz}$ & $170 \mathrm{~Hz}$ & $35 \mathrm{~Hz}$ & $11 \mathrm{kno}$ & $256 \mathrm{~Hz}$ & $225 \mathrm{~Hz}$ & $201 \mathrm{~Hz}$ & $215 \mathrm{~Hz}$ & $25 \mathrm{~Hz}$ \\
\hline $5 \mathrm{kty}$ & $234 \mathrm{~Hz}$ & $228 \mathrm{~Hz}$ & $162 \mathrm{~Hz}$ & $185 \mathrm{~Hz}$ & $67 \mathrm{~Hz}$ & $12 \mathrm{kno}$ & $178 \mathrm{~Hz}$ & $166 \mathrm{~Hz}$ & $137 \mathrm{~Hz}$ & $170 \mathrm{~Hz}$ & $29 \mathrm{~Hz}$ \\
\hline $6 \mathrm{mty}$ & $180 \mathrm{~Hz}$ & $167 \mathrm{~Hz}$ & $136 \mathrm{~Hz}$ & $157 \mathrm{~Hz}$ & $31 \mathrm{~Hz}$ & $13 \mathrm{mno}$ & $135 \mathrm{~Hz}$ & $101 \mathrm{~Hz}$ & $83 \mathrm{~Hz}$ & $131 \mathrm{~Hz}$ & $17 \mathrm{~Hz}$ \\
\hline $7 \mathrm{mty}$ & $151 \mathrm{~Hz}$ & $144 \mathrm{~Hz}$ & $134 \mathrm{~Hz}$ & $153 \mathrm{~Hz}$ & $10 \mathrm{~Hz}$ & $14 \mathrm{mno}$ & $134 \mathrm{~Hz}$ & $112 \mathrm{~Hz}$ & $106 \mathrm{~Hz}$ & $138 \mathrm{~Hz}$ & $6 \mathrm{~Hz}$ \\
\hline
\end{tabular}

\section{Oppsummering av aksent 1-frasene hos de tyske S2- og de norske S1-talerne}

Når vi studerer kurvene i de foregående figurene og sammenholder dem med f0-verdiene i tabell 1 og 2 , ser vi at forskjellen i frekvens mellom vokalstart og vokalslutt er svært ulik hos de tyske studentene, men langt likere hos de norske S1-talerne. De to kvinnelige S2-talerne 1 kty og 5 kty skiller seg klart ut med et fall på henholdsvis 59 og $67 \mathrm{~Hz}$ i gjennomsnitt. S2-taleren 4 kty har et fall på $35 \mathrm{~Hz}$, men hun har gjennomgående kortere vokalvarighet enn de andre tyske. Av figurene ser vi at også S2-taleren 3 kty har kortere vokalvarighet, men vokalkurvene til 3 kty har et mer varierende forløp, mens den kvinnelige tyske taleren 2 kty skiller seg ut med en stigende kurve i alle vokalene. Den mannlige S2-taleren 6 mty har også et fall i vokalkurvene (tydelig i huset og barnet). Av kurvene og tabellene ser vi at tonen (toneleiet) generelt er høyere hos de tyske enn hos de norske. Tonegangen hos de østnorske S1-talerne sammenfaller i stor grad med Kristoffersens modell (figur 1) for aksent 1, mens ingen av de tyske talerne har en tonegang som likner den østnorske aksent 1. I tabell 2 har riktignok den kvinnelige tyske S2-taleren3 kty høyere utgangsfrekvens, et moderat fall i den trykksterke vokalen og høyere frekvens i den påfølgende stavelsen slik beskrivelsen av aksent 1 tilsier, men når hun ikke har en østnorsk tonegang, er det fordi hun har betraktelig variasjon mellom de ulike ordene. Gjennomgående har likevel den enkelte tyske S2-taler en forholdsvis ensartet og stabil uttale av alle de fem aksent 1-ordene, men den individuelle variasjonen S2-talerne imellom er ganske stor. 


\section{Uttale av aksent 2 hos norske S1-talere}

De fem ordene som inngikk i granskingen av aksent 2, var sure (Det sure barnet hylte høyt), pene (Hun kjører gjerne pene biler), fine (Hun mistet den fine pennen), dyre og gule (De dyre mattene var gule og svarte). Hos de norske S1-talerne har jeg til sammen analysert 35 ord (7 informanter $\times 5$ ord, aksentfraser).

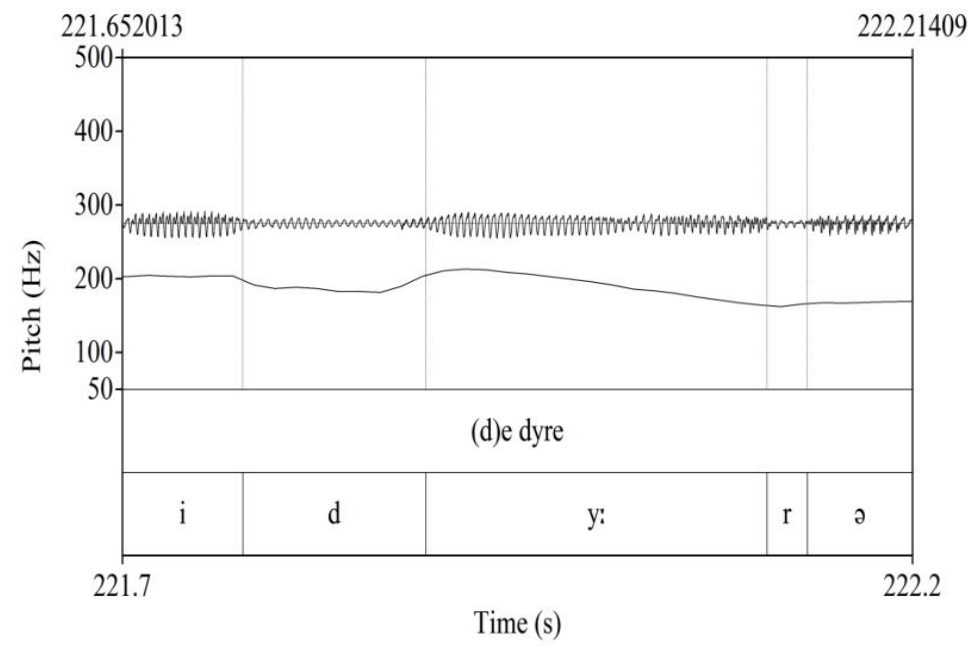

Figur 15: frasen «De dyre» hos taleren 8 kno

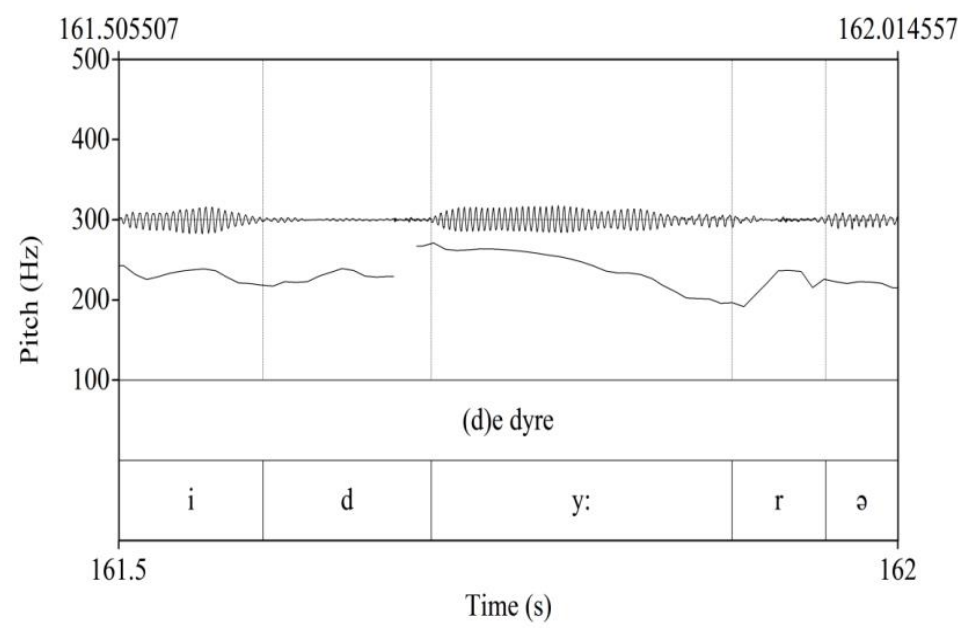

Figur 16: frasen «De dyre» hos taleren 11 kno

Hos begge disse norske kvinnelige S1-talerne ( 8 kno og 11 kno) ser vi at tonekurvens høyeste område er ved begynnelsen av den aksentuerte vokalen /y:/. Det skjer en stigning mot dette området, og kurvens laveste nivå er helt i begynnelsen av etterfølgende trykklette stavelse. Vi ser også her at 11 kno har høyere frekvensverdier enn 8 kno. 


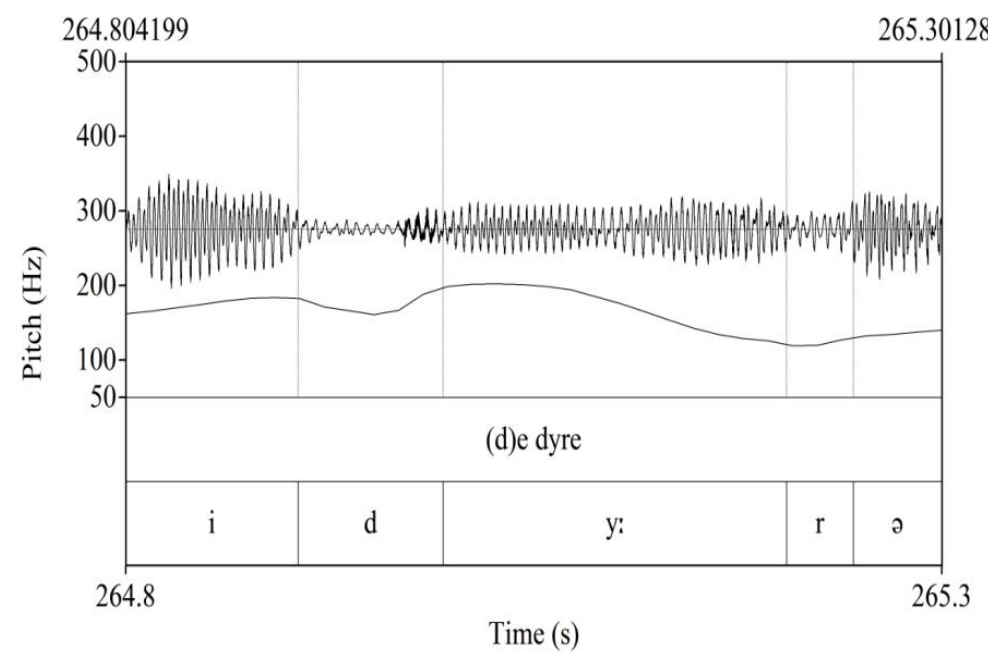

Figur 17: frasen «De dyre» hos S1-taleren 13 mno

Også hos denne norske S1-taleren, 13 mno (figur 17), ser vi det samme mønsteret: F0-kurvens høyeste område er ved begynnelsen av den lange trykksterke vokalen eller litt senere. Kurvens laveste nivå kommer tidlig i trykklett stavelse etter /y:/; altså i overensstemmelse med modellen for aksent 2 (figur 1). Den bratte stigningen på siste stavelse ved aksent 2 i modellen flates vel noe ut av setningsintonasjonen.

\section{Uttale av aksent 2 hos de tyske S2-talerne}

Hos de tyske studentene har jeg analysert til sammen 35 ord som i østnorsk uttales med aksent 1, men bare 33 ord med aksent 2. De to ordene «pene» og «fine» hos den kvinnelige tyske studenten 4 kty kunne ikke analyseres på grunn av feil i opptaket. Totalt har jeg derfor analysert 68 ord fra de tyske S2-talerne.

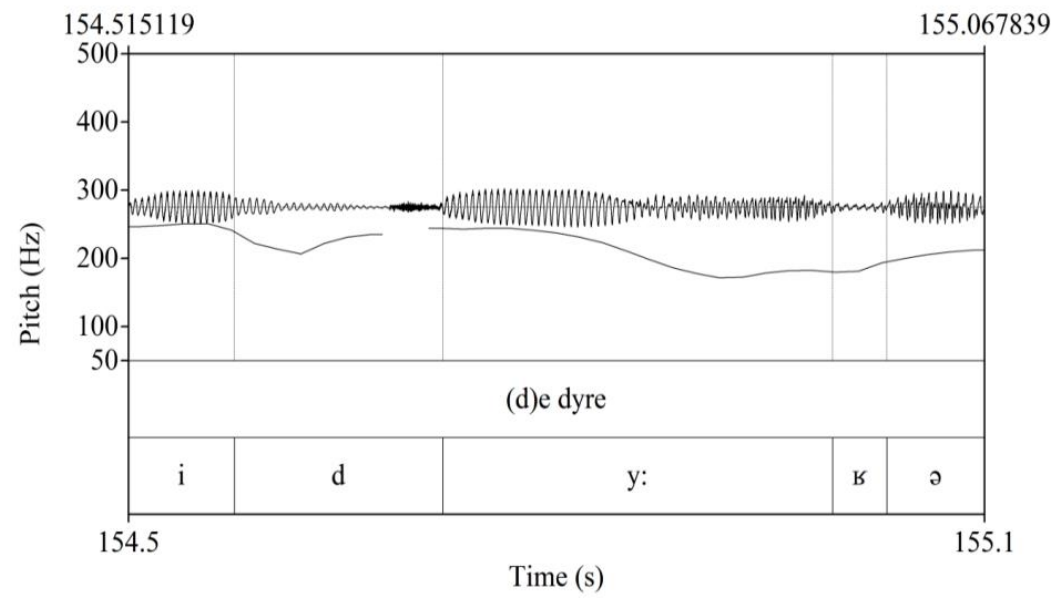

Figur 18: frasen «De dyre» hos S2-taleren 1 kty

Hos 1 kty ser vi høy tone ved den trykksterke vokalens begynnelse, men kurvens laveste område er også inne i vokalen. Hvis vi sammenlikner denne kurven med hennes kurve for aksent 1-ordet bilen (figur 7), ser vi et noe ulikt mønster. Både kurven i figur 7 og i figur 18 har høyest tone ved den trykksterke vokalens 
begynnelse, men i figur 18 kommer kurvens laveste område tidligere. Det samme mønsteret ser vi hos den tyske taleren 6 mty (figur 19).

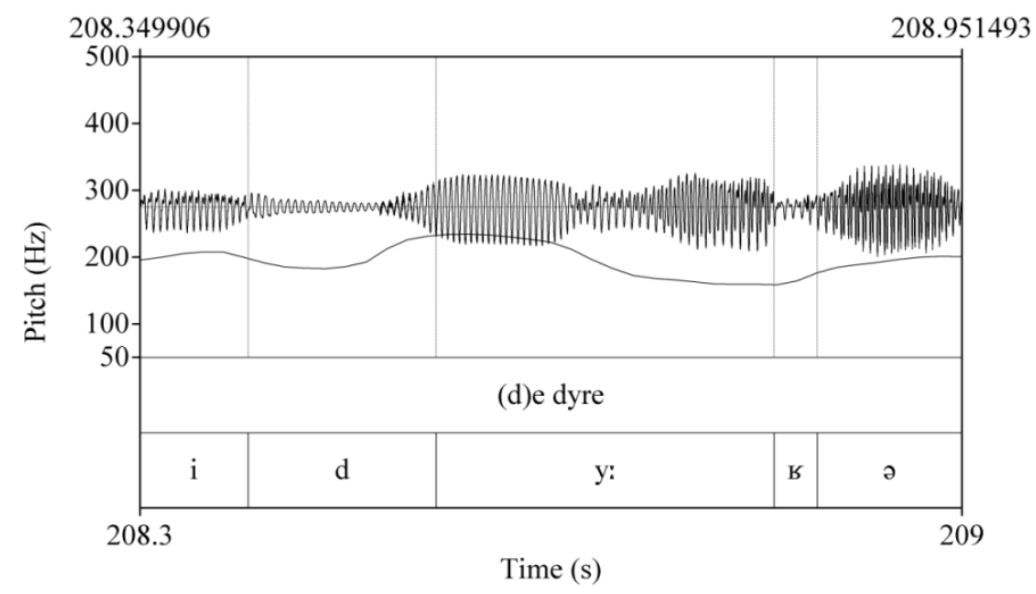

Figur 19: frasen «De dyre» hos S2-taleren 6 mty

Hos S2-taleren 4 kty (figur 20) ser vi derimot et annet tonebilde:

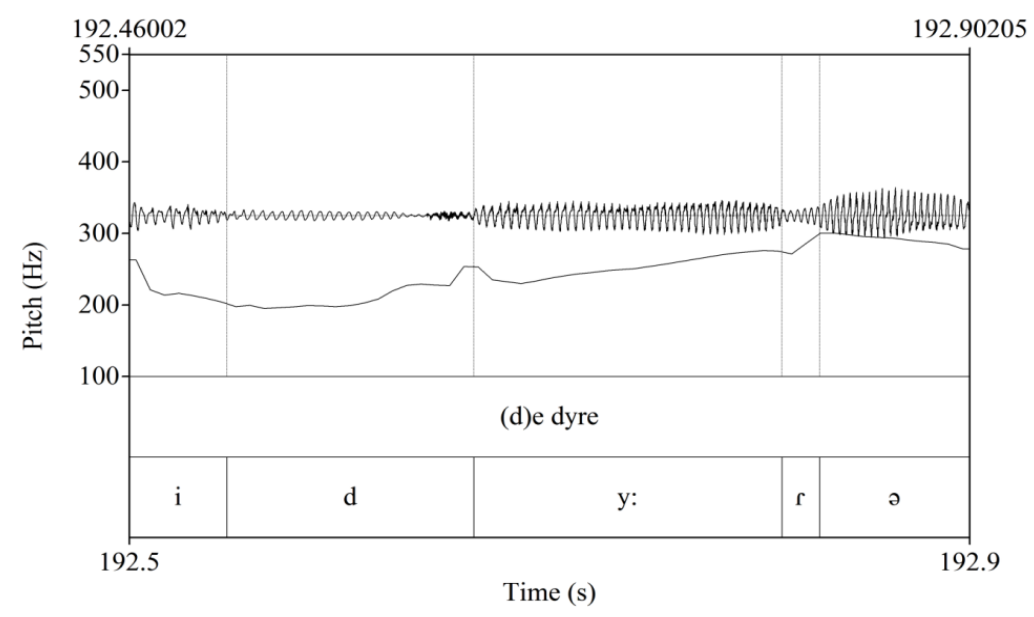

Figur 20: aksentfrasen «De dyre» hos S2-taleren 4 kty

Hos informant 4 kty stiger tonen gjennom hele den trykksterke vokalen /y:/. Frasen «De dyre» hos disse tre tyske informantene (figur 18-20) skiller seg klart fra aksent 2-tonegangen hos de norske informantene. Vi kan skille ut to ulike toneganger hos de tyske S2-talerne ved aksent 2-ordene: 1, 3, 5 og 6 har en fallende tone med kurvens laveste område rundt eller litt etter midten av vokalen, mens 2, 4 og 7 har en stigende tone (se figur 21a). 

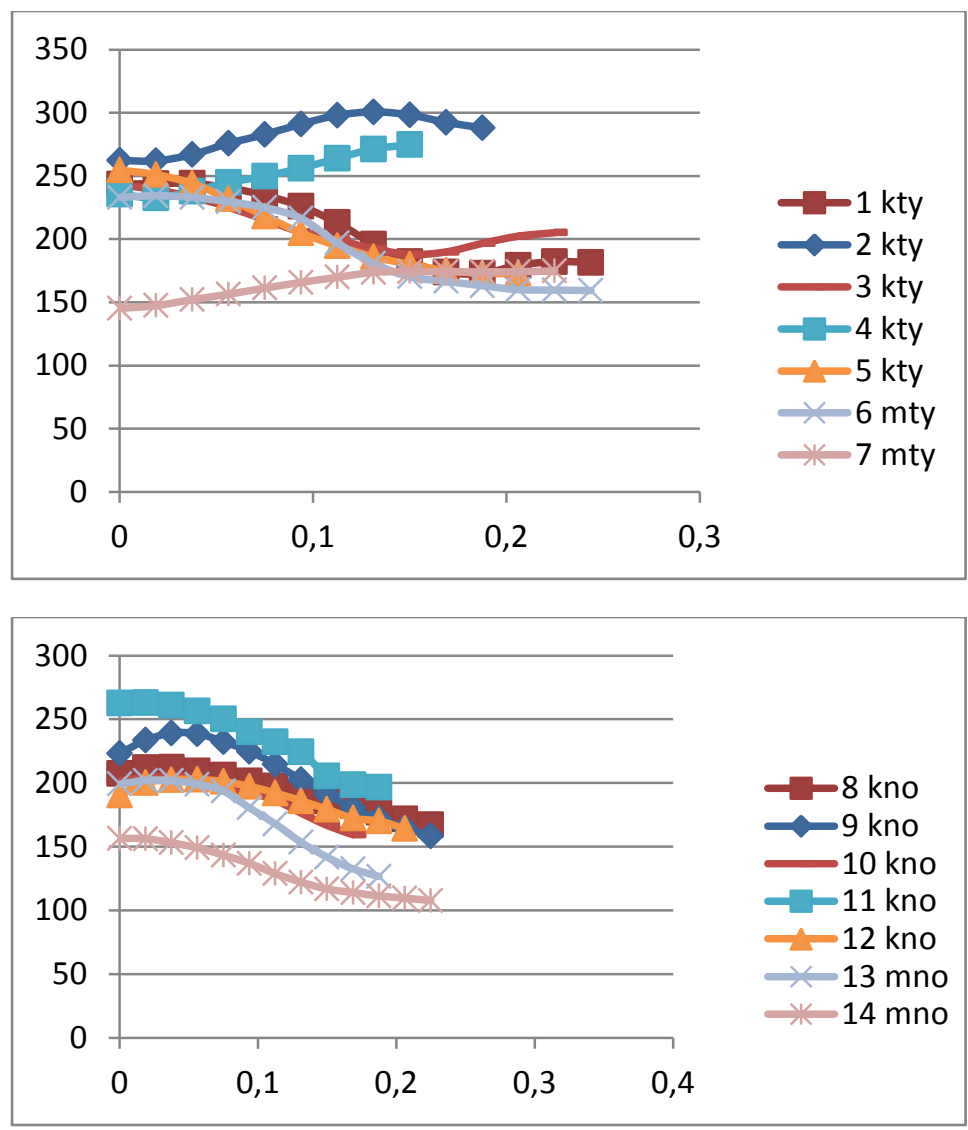

21 a) «dyre», lang vokal /y:/ - tysk

21 b) «dyre», lang vokal /y:/ - norsk

Figur 21 a) og b): Lang trykksterk vokal hos de tyske og norske talerne ved aksent 2-ordet «dyre»
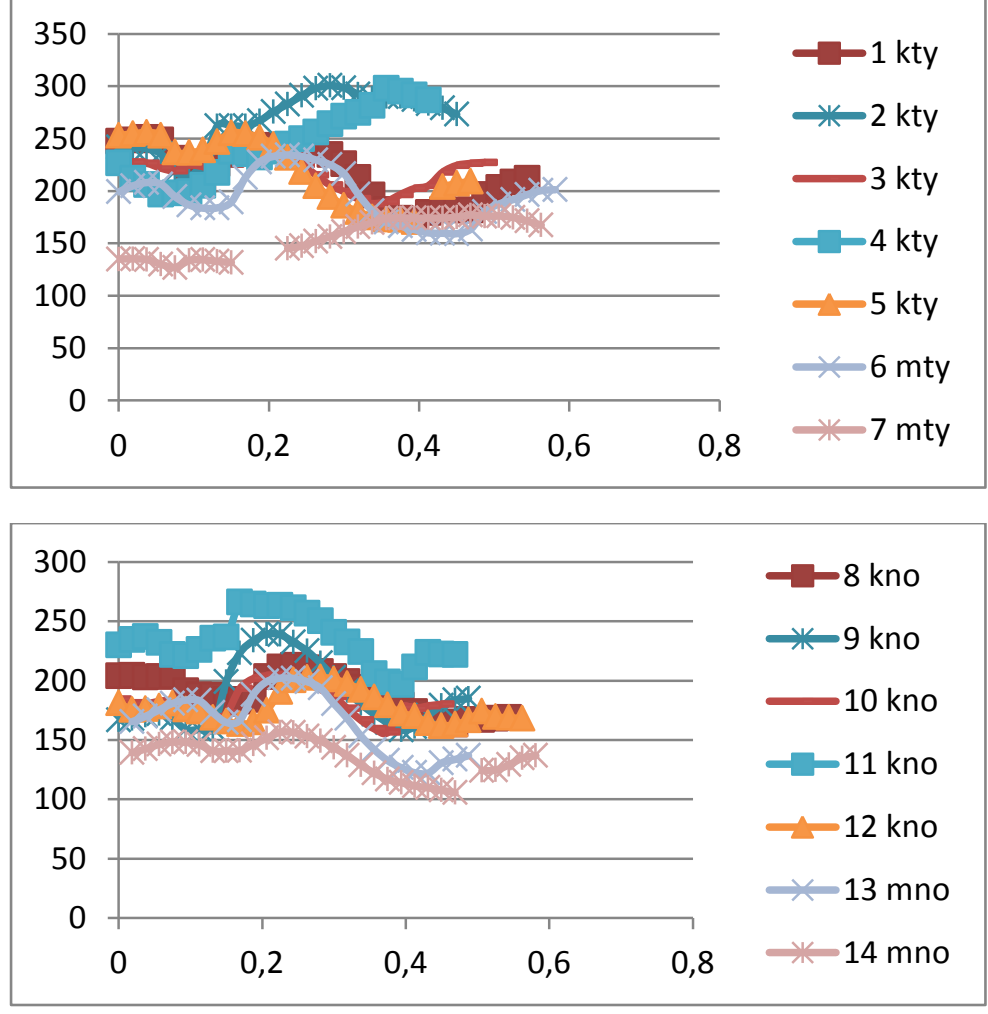

22 a) frasen «De dyre»-tysk

22 b) frasen «De dyre»- norsk

Figur 22 a) og b): Aksentfraser hos de tyske og norske talerne i frasen «De dyre» 
Tabell 3: f0 ved trykksterk vokals begynnelse og slutt i frasen «De dyre» hos de tyske og norske informantene. (Her er «a» målt omtrent midt i den trykklette vokalen før aksentfrasens begynnelse, «n» er målt i siste stavelse $\mathrm{i}$ «dyre». «Forskj.» er frekvensforskjellen mellom start og slutt av den trykksterke vokalen /y:/.)

\begin{tabular}{|c|c|c|c|c|c|c|c|c|c|c|c|c|}
\hline $\begin{array}{c}\text { Inf. } \\
\text { tysk }\end{array}$ & a & $\begin{array}{c}\text { Vokal } \\
\text { start }\end{array}$ & $\begin{array}{c}\text { Vokal } \\
\text { slutt }\end{array}$ & $\mathbf{n}$ & Forskj. & $\begin{array}{c}\text { Inf. } \\
\text { norsk }\end{array}$ & a & $\begin{array}{c}\text { Vokal } \\
\text { start }\end{array}$ & $\begin{array}{c}\text { Vokal } \\
\text { slutt }\end{array}$ & n & Forskj. \\
\hline $1 \mathrm{kty}$ & $251 \mathrm{~Hz}$ & $244 \mathrm{~Hz}$ & $182 \mathrm{~Hz}$ & $208 \mathrm{~Hz}$ & $62 \mathrm{~Hz}$ & $8 \mathrm{kno}$ & $203 \mathrm{~Hz}$ & $207 \mathrm{~Hz}$ & $167 \mathrm{~Hz}$ & $169 \mathrm{~Hz}$ & $40 \mathrm{~Hz}$ \\
\hline $2 \mathrm{kty}$ & $240 \mathrm{~Hz}$ & $262 \mathrm{~Hz}$ & $288 \mathrm{~Hz}$ & $283 \mathrm{~Hz}$ & $-26 \mathrm{~Hz}$ & $9 \mathrm{kno}$ & $171 \mathrm{~Hz}$ & $223 \mathrm{~Hz}$ & $158 \mathrm{~Hz}$ & $184 \mathrm{~Hz}$ & $65 \mathrm{~Hz}$ \\
\hline $3 \mathrm{kty}$ & $226 \mathrm{~Hz}$ & $243 \mathrm{~Hz}$ & $205 \mathrm{~Hz}$ & $226 \mathrm{~Hz}$ & $38 \mathrm{~Hz}$ & $10 \mathrm{kno}$ & $180 \mathrm{~Hz}$ & $202 \mathrm{~Hz}$ & $159 \mathrm{~Hz}$ & $179 \mathrm{~Hz}$ & $42 \mathrm{~Hz}$ \\
\hline $4 \mathrm{kty}$ & $197 \mathrm{~Hz}$ & $236 \mathrm{~Hz}$ & $275 \mathrm{~Hz}$ & $291 \mathrm{~Hz}$ & $-39 \mathrm{~Hz}$ & $11 \mathrm{kno}$ & $237 \mathrm{~Hz}$ & $263 \mathrm{~Hz}$ & $197 \mathrm{~Hz}$ & $222 \mathrm{~Hz}$ & $66 \mathrm{~Hz}$ \\
\hline $5 \mathrm{kty}$ & $256 \mathrm{~Hz}$ & $255 \mathrm{~Hz}$ & $173 \mathrm{~Hz}$ & $204 \mathrm{~Hz}$ & $82 \mathrm{~Hz}$ & $12 \mathrm{kno}$ & $178 \mathrm{~Hz}$ & $190 \mathrm{~Hz}$ & $164 \mathrm{~Hz}$ & $169 \mathrm{~Hz}$ & $26 \mathrm{~Hz}$ \\
\hline $6 \mathrm{mty}$ & $208 \mathrm{~Hz}$ & $233 \mathrm{~Hz}$ & $159 \mathrm{~Hz}$ & $192 \mathrm{~Hz}$ & $74 \mathrm{~Hz}$ & $13 \mathrm{mno}$ & $175 \mathrm{~Hz}$ & $199 \mathrm{~Hz}$ & $127 \mathrm{~Hz}$ & $131 \mathrm{~Hz}$ & $72 \mathrm{~Hz}$ \\
\hline $7 \mathrm{mty}$ & $135 \mathrm{~Hz}$ & $145 \mathrm{~Hz}$ & $175 \mathrm{~Hz}$ & $175 \mathrm{~Hz}$ & $-30 \mathrm{~Hz}$ & $14 \mathrm{mno}$ & $146 \mathrm{~Hz}$ & $156 \mathrm{~Hz}$ & $108 \mathrm{~Hz}$ & $129 \mathrm{~Hz}$ & $49 \mathrm{~Hz}$ \\
\hline
\end{tabular}

Av tabell 3 ser vi det vi kunne lese ut av vokalkurvene til de tyske talerne i figur 21 a) og 22 a): De deler seg i to grupper: informantene 2, 4 og 7 har en klar negativ forskjell mellom vokalbegynnelse og vokalslutt, dvs. en stigende kurve, mens de fire resterende tyske talerne 1, 3, 5 og 6 har en fallende kurve i den aksentuerte vokalen med en utflating i siste halvdel av vokalen og eventuelt en mindre stigning. Muligens skulle jeg også ha målt kurvenes høyeste og laveste punkt, men av rent praktiske grunner har jeg valgt bare å tallfeste vokalkurvens begynnelse og slutt. Figurene 21 a) og 23 a) - d) viser klarere variasjonene i tonebevegelsen enn flere tall ville gjøre. Hos de norske informantene har tonekurvene et nesten identisk forløp: et klart fall mot kurvens laveste nivå. Vi ser av tabell 3 at «n» (trykklett stavelse etter den aksentuerte vokalen) har høyere frekvensverdier enn vokalslutt hos alle de norske informantene, men av figurene 15 - 17 ser vi at aksent 2-kurvens laveste nivå kommer svært tidlig i den trykklette stavelsen slik at midt i den trykklette stavelsen der jeg har målt, har aksent 2-kurven allerede begynt å stige. Når det gjelder forholdet mellom trykklett vokal før aksentfrasens begynnelse, «a» i tabellen, ser vi at «a» har lavere verdier enn verdiene for vokalstart hos alle de norske informantene, mens de tyske talerne 1 kty og 5 kty har litt høyere verdier $\mathrm{i}$ «a». De andre S2-talerne har lavere verdier i «a».

I figur 23 a) - d) og 24 a) - d) kan vi studere vokalkurvene i de fire resterende aksent 2-ordene (gule, sure, fine og pene) hos både S2- og S1-talerne. Av de fire vokalkurvene i figur 23 ser vi at også for aksent 2ordene er de individuelle kurveforløpene hos de tyske studentene forholdsvis stabile. Talerne 1, 3, 5 og 6 har fallende kurver, mens 2, 4 (bare målt i to av ordene) og 7 har stigende vokalkurver. Informantene 1 og 5 er begge fra Nord-Tyskland, og det er disse to som skiller seg klarest ut med en tydelig fallende tonegang $\mathrm{i}$ begge aksenter. S1-talerne har nærmest identiske vokalforløp, men noe ulik vokalvarighet. S1-taleren 1 kty har bare fire måneders oppholdstid i Norge, mens 4 kty har samlet oppholdstid i Norge på over to år. 

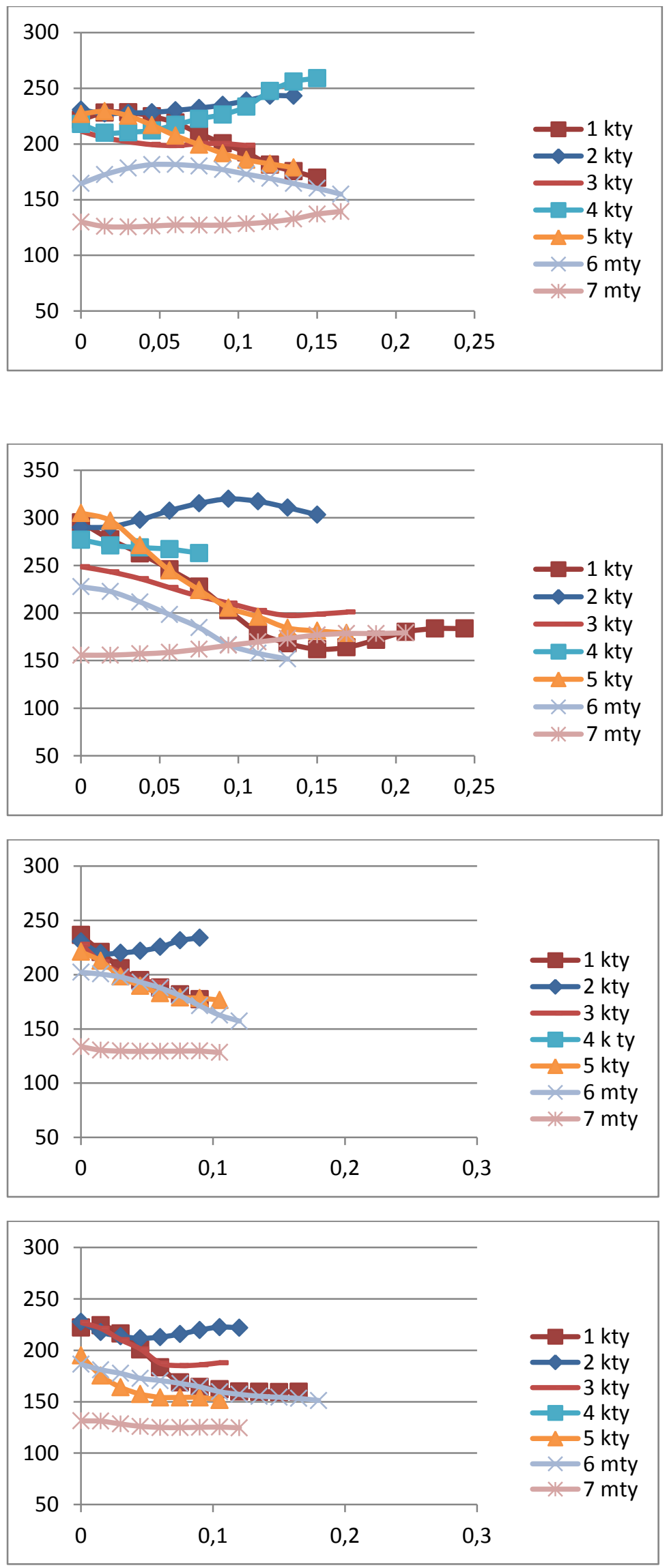

23 a) «gule», lang vokal /u:/ / - tysk

23 b) «sure», lang vokal /u:/ - tysk

23 c) «fine», lang vokal /i:/ - tysk ${ }^{2}$

23 d) «pene», lang vokal /e:/ - tysk ${ }^{2}$

Figur 23 a), b), c) og d): tonegangen i de lange vokalene /u:/, /i:/ og /e:/ i de fire ordene «gule», «sure», «fine» og «pene» hos de tyske S2-talerne

\footnotetext{
${ }^{2}$ Informant 4 kty er ikke med her
} 

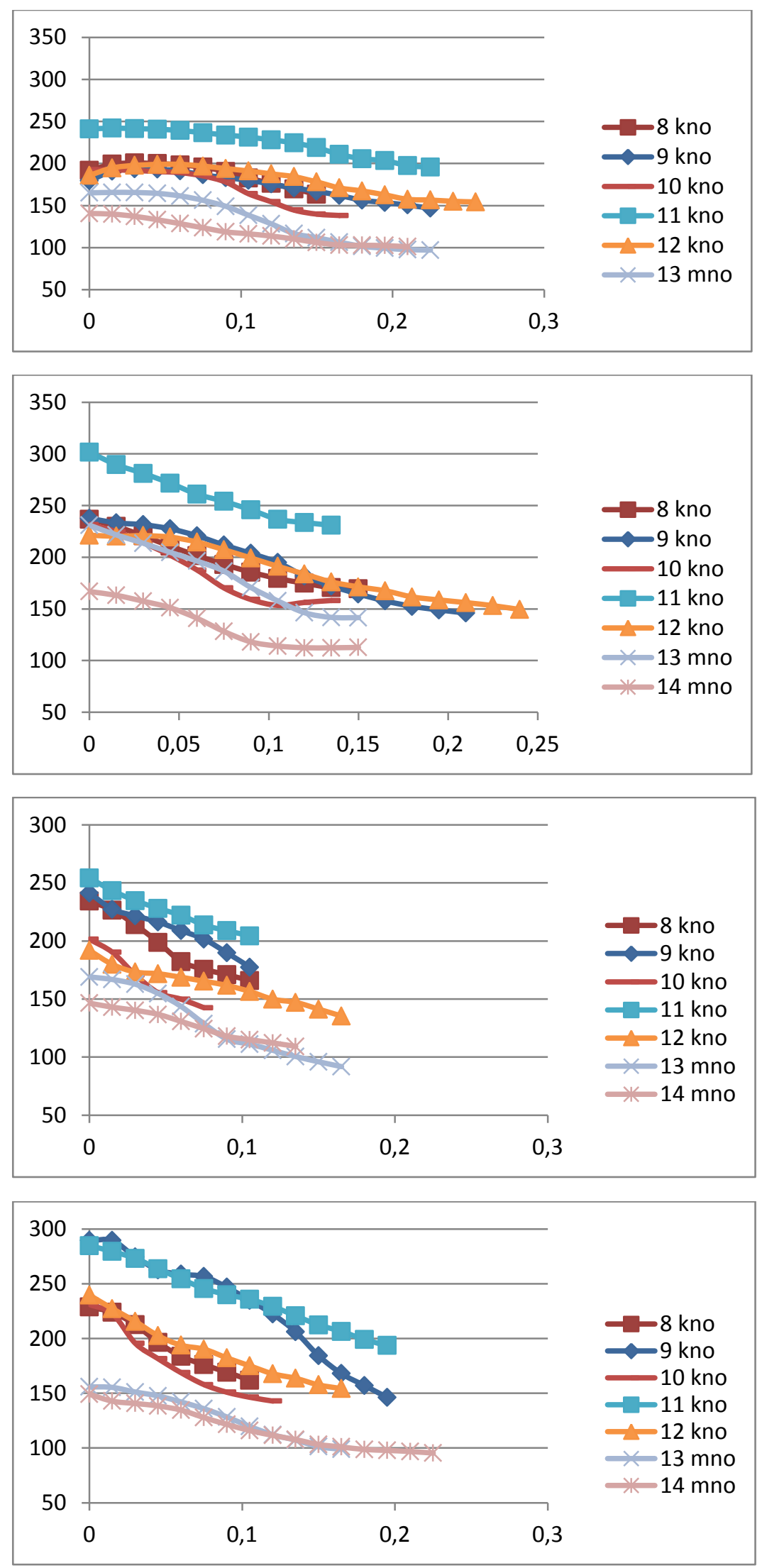

24 a) «gule», lang vokal /u./ - norsk

24 b) «sure», lang vokal /tt:/ - norsk

24 c) «fine», lang vokal /i:/ - norsk

$24 d)$ «pene», lang vokal /e:/ - norsk

Figur $24(a), b), c)$ og $d$ ): tonegangen $i$ de lange vokalene /u:/, /i:/ og /e:/ i de fire ordene «gule», «sure», «fine» og «pene» hos de norske informantene. 
Tabell 4: Gjennomsnittsverdier for f0 ved vokalbegynnelse og vokalslutt i de fem aksent 2-ordene «dyre», «gule», «sure», «fine» og «pene» hos de tyske og norske informantene. (Her er «a» målt omtrent midt i den trykklette vokalen før aksentfrasens begynnelse, «n» er målt i den siste stavelsen i de fem ordene. Variasjonen i «n» kan knyttes til ulik setningsintonasjon både hos de tyske og norske informantene. «Forskj.» er forskjellen mellom begynnelse og slutt av de trykksterke vokalene /y:/, /u:/,/e:/,/i:/.)

\begin{tabular}{|l|c|c|c|c|c|c|c|c|c|c|c|}
\hline $\begin{array}{l}\text { Inf. } \\
\text { tysk }\end{array}$ & $\mathbf{a}$ & $\begin{array}{l}\text { Vokal } \\
\text { start }\end{array}$ & $\begin{array}{l}\text { Vokal } \\
\text { slutt }\end{array}$ & $\mathbf{n}$ & Forskj. & $\begin{array}{l}\text { Inf. } \\
\text { norsk }\end{array}$ & $\mathbf{a}$ & $\begin{array}{l}\text { Vokal } \\
\text { start }\end{array}$ & $\begin{array}{l}\text { Vokal } \\
\text { slutt }\end{array}$ & $\mathbf{n}$ & Forskj. \\
\hline $1 \mathrm{kty}$ & $245 \mathrm{~Hz}$ & $244 \mathrm{~Hz}$ & $174 \mathrm{~Hz}$ & $192 \mathrm{~Hz}$ & $69 \mathrm{~Hz}$ & $8 \mathrm{kno}$ & $203 \mathrm{~Hz}$ & $219 \mathrm{~Hz}$ & $166 \mathrm{~Hz}$ & $165 \mathrm{~Hz}$ & $54 \mathrm{~Hz}$ \\
\hline $2 \mathrm{kty}$ & $236 \mathrm{~Hz}$ & $247 \mathrm{~Hz}$ & $259 \mathrm{~Hz}$ & $248 \mathrm{~Hz}$ & $-11 \mathrm{~Hz}$ & $9 \mathrm{kno}$ & $176 \mathrm{~Hz}$ & $234 \mathrm{~Hz}$ & $155 \mathrm{~Hz}$ & $183 \mathrm{~Hz}$ & $79 \mathrm{~Hz}$ \\
\hline $3 \mathrm{kty}$ & $218 \mathrm{~Hz}$ & $232 \mathrm{~Hz}$ & $197 \mathrm{~Hz}$ & $211 \mathrm{~Hz}$ & $35 \mathrm{~Hz}$ & $10 \mathrm{kno}$ & $178 \mathrm{~Hz}$ & $212 \mathrm{~Hz}$ & $148 \mathrm{~Hz}$ & $172 \mathrm{~Hz}$ & $63 \mathrm{~Hz}$ \\
\hline $4 \mathrm{kty}$ & $208 \mathrm{~Hz}$ & $248 \mathrm{~Hz}$ & $266 \mathrm{~Hz}$ & $278 \mathrm{~Hz}$ & $-18 \mathrm{~Hz}$ & $11 \mathrm{kno}$ & $245 \mathrm{~Hz}$ & $268 \mathrm{~Hz}$ & $204 \mathrm{~Hz}$ & $236 \mathrm{~Hz}$ & $64 \mathrm{~Hz}$ \\
\hline $5 \mathrm{kty}$ & $255 \mathrm{~Hz}$ & $240 \mathrm{~Hz}$ & $172 \mathrm{~Hz}$ & $189 \mathrm{~Hz}$ & $69 \mathrm{~Hz}$ & $12 \mathrm{kno}$ & $167 \mathrm{~Hz}$ & $206 \mathrm{~Hz}$ & $151 \mathrm{~Hz}$ & $155 \mathrm{~Hz}$ & $55 \mathrm{~Hz}$ \\
\hline $6 \mathrm{mty}$ & $191 \mathrm{~Hz}$ & $202 \mathrm{~Hz}$ & $154 \mathrm{~Hz}$ & $178 \mathrm{~Hz}$ & $48 \mathrm{~Hz}$ & $13 \mathrm{mno}$ & $142 \mathrm{~Hz}$ & $184 \mathrm{~Hz}$ & $111 \mathrm{~Hz}$ & $135 \mathrm{~Hz}$ & $73 \mathrm{~Hz}$ \\
\hline $7 \mathrm{mty}$ & $136 \mathrm{~Hz}$ & $139 \mathrm{~Hz}$ & $149 \mathrm{~Hz}$ & $156 \mathrm{~Hz}$ & $-10 \mathrm{~Hz}$ & $14 \mathrm{mno}$ & $134 \mathrm{~Hz}$ & $152 \mathrm{~Hz}$ & $105 \mathrm{~Hz}$ & $119 \mathrm{~Hz}$ & $46 \mathrm{~Hz}$ \\
\hline
\end{tabular}

\section{Oppsummering av aksent 2-frasene hos de tyske S2- og de norske S1-talerne}

Da vi oppsummerte vokalkurvene for aksent 1-ordene, skilte de to S2-talerne 1 kty og 5 kty seg klart ut med et fall på henholdsvis rundt 60 og i underkant av $70 \mathrm{~Hz}$ i gjennomsnitt. Disse to S2-talerne skiller seg ut på samme måte når det gjelder aksent 2-ordene. Her har de begge 69 hertz i gjennomsnittlig nivåforskjell mellom begynnelse og slutt av den trykksterke vokalen, altså ganske lik en norsk aksent 2-kontur, men ettersom de har omtrent samme kontur for aksent 1-ordene, skiller de altså ikke mellom de to aksentene. S2taleren 4 kty plasserte seg i gruppe med 1 kty og 5 kty når det gjaldt aksent 1 -ord med en fallende kurve i den trykksterke vokalen, men med svært kort vokalvarighet. Når det gjelder tonebevegelsen til 4 kty i aksent 2-ordene, ser vi at særlig dyre og gule har klart stigende kurver hos 4 kty. Hun gjør forskjell på de to aksentene, men har en stigende tone i aksent 1-ordet bilen slik hun har i aksent 2-ordene. S2-taleren 4 kty har altså et skille, men ikke et stabilt skille mellom de to aksentene. Av figurene og tabell 3 og 4 ser vi at også informant 7 mty plasserer seg klart i denne gruppa med stigende eller jevn vokalkurve fra start til slutt ved aksent 2-ordene. Disse tre talerne 2 kty, 4 kty og 7 mty oppgir å komme fra sør og (sør)vest i Tyskland. S2-talerne 3 kty og 6 mty har fallende kurver ved aksent 2-ordene. Hvis vi ser på gjennomsnittsverdiene deres i tabell 2 og 4 ser vi også hos dem liten forskjell i verdiene for aksent 1- og aksent 2-ordene. Når det gjelder tonebevegelsen hos de norske S1-talerne, er den lik i form dem i mellom, kurvenes kontur er lik aksent 2-kurven i figur 1, vokalvarigheten varierer noe, og taleren 11 kno skiller seg gjennomgående ut når det gjelder tonenivå.

\footnotetext{
${ }^{3}$ Gjelder gjennomsnitt for tre ord: «dyre», «gule», «sure»
} 


\section{Sammenfatning}

De to tyske mannlige S2-talerne, $6 \mathrm{mty}$ og $7 \mathrm{mty}$, har et høyere toneleie enn de to norske mennene. Vokalstart er hos S2-talerne i gjennomsnitt $50 \mathrm{~Hz}$ høyere enn hos de norske ved aksent 1-ordene og ved vokalslutt i underkant av $40 \mathrm{~Hz}$ høyere. Ut fra dette kunne vi si at hypotesen om at tyske S2-talere ville produsere norsk aksent 1 med en høyere tone enn norske S1-talere i den aksentuerte stavelsen, er bekreftet, men av kurvene og tabellene ser vi at tonen generelt er høyere hos de tyske enn hos de norske talerne. Hvis vi ser på forskjellen mellom vokalstart og vokalslutt ved aksent 2-ordene er den mellom -7 og 71 Hz hos S2talerne, men langt likere hos de norske informantene der den høyeste verdien er $83 \mathrm{~Hz}$ og den laveste $46 \mathrm{~Hz}$ (tabell 4). Hvis vi sammenlikner tonehøyden i «a», altså utgangstonen før realiseringen av de to aksentene, finner vi at gjennomsnittet for de tyske talerne ligger cirka $35 \mathrm{~Hz}$ høyere ved aksent 1-ordene enn hos de norske. Ved aksent 2-ordene (minus 4 kty og 11 kno) er tonehøyden cirka $47 \mathrm{~Hz}$ høyere hos de tyske informantene. I en akustisk studie av toneaksentene i svensk hos finske innlærere finner Kuronen (2015) at «röstläget» (norsk: toneleiet) hos de svenske S1-brukerne er $50 \mathrm{~Hz}$ høyere enn hos de finske S2-brukerne av svensk. Kuronen sier også at f0-toppen var høyere i begge aksentene hos S1-talerne. Altså for så vidt det omvendte av hva min granskning viser, der det er de tyske S2-talerne som gjennomgående har det høyeste toneleiet. Kuronen viser også til forskningen til Wang m.fl. (2003) som viser at nivåtoner er vanskeligere å lære enn konturtoner. "Contour tone" defineres hos Yip (2002) som "A tone that changes pitch during its duration, either rising or falling." Toneaksentene kan slik defineres som konturtoner.

Funnene når det gjelder forskjellene i toneleie mellom de tyske S1- og de norske S2-talerne, overlater jeg til videre forskning i et større materiale, og betydningen de eventuelt har for opplevd innfødtlikhet, kan bare avgjøres ved persepsjonsstudier. Tonehøyden er også avhengig av resonnansrommets (munnhulens) størrelse slik at høy tone hos et barn er høyere enn hos en voksen.

Tonegangen hos de østnorske S1-talerne sammenfaller i stor grad med Kristoffersens modell (figur 1) for både aksent 1- og aksent 2-ordene, men siste del av begge konturene vil variere med setningsintonasjonen hos den enkelte. Tonehøyden for de to aksentkurvene i den fonologiske modellen i figur 1 er høyere enn hos seks av de sju S1-talerne (jf. figur 25).

Ingen av de tyske S2-talerne har en tonegang som er lik den østnorske, men den enkelte tyske informant har en forholdsvis ensartet og stabil uttale av de fem ordene i hver gruppe, særlig gjelder det de fem aksent 2-ordene. Her har de fire hovedsakelig nordtyske S2-talerne 1 kty, 3 kty, 5 kty og 6 mty et klart fall i den aksentuerte vokalen, mens de $\varnothing$ vrige tre sør- og vest-tyske S2-talerne 2 kty, 4 kty og 7 mty har en forholdsvis jevn eller lett stigende tone i den trykksterke vokalen. Muligens har disse tre en tonegang $\mathrm{i}$ aksentuert stavelse som er mer i overensstemmelse med den standardtyske tonekonturen i figur 2. Uttalen til de første fire S2-talerne ligner østnorsk aksent 2-uttale, men kurvens laveste nivå kommer tidligere i vokalen enn hos de østnorske S1-talerne som har kurvens laveste område i trykklett stavelse etter den aksentuerte vokalen. Det er noe større usikkerhet når det gjelder uttalen av aksent 1-ordene hos de tyske studentene, og sånn sett kan vi si at det er de østnorske aksent 1-ordene som skaper størst problemer eller usikkerhet hos 
S2-talerne. De to tyske studentene 2 kty og 7 mty har stabil og lik uttale i de fem aksent 1-ordene, mens 3 kty og 6 mty og delvis 4 kty har en noe ustabil uttale. Når det gjelder uttalen av de to østnorske toneaksentene av S2-talerne, kan det altså se ut som om studentene grupperer seg etter hvor i Tyskland de kommer fra slik at de som kommer fra Nord-Tyskland har en litt annen tonegang i trykksterk vokal enn de som kommer fra sør. Ingen av de sju tyske S2-talerne skiller klart mellom de to toneaksentene i østnorsk. Figur 25 er en sammenliknende framstilling av gjennomsnittsverdiene hos både S1- og S2-talerne for begge aksenter. Den kan avslutningsvis illustrere den foregående sammenfatningen:

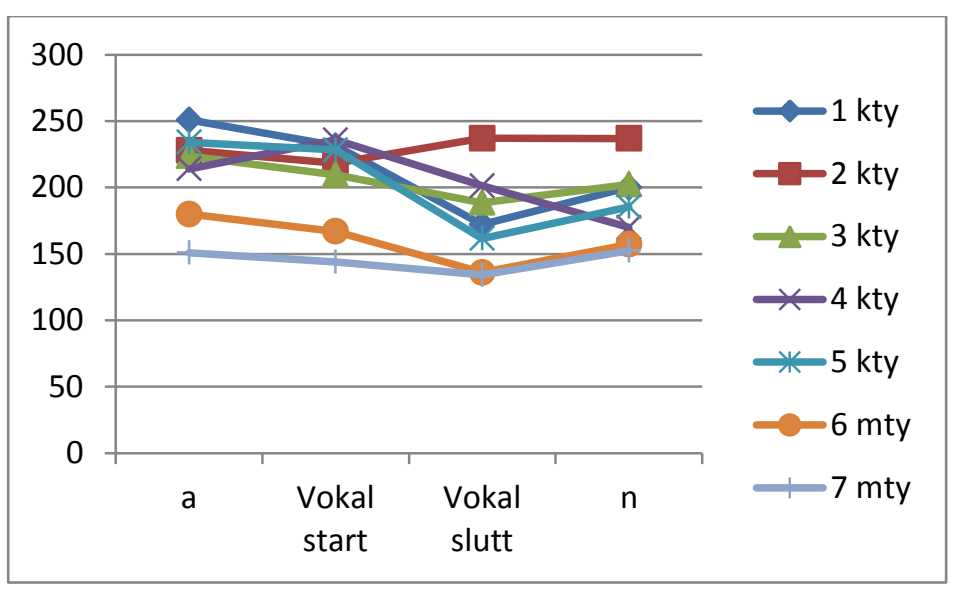

Aksent 1 - tyske talere (barnet, maten, bilen, huset, varet)

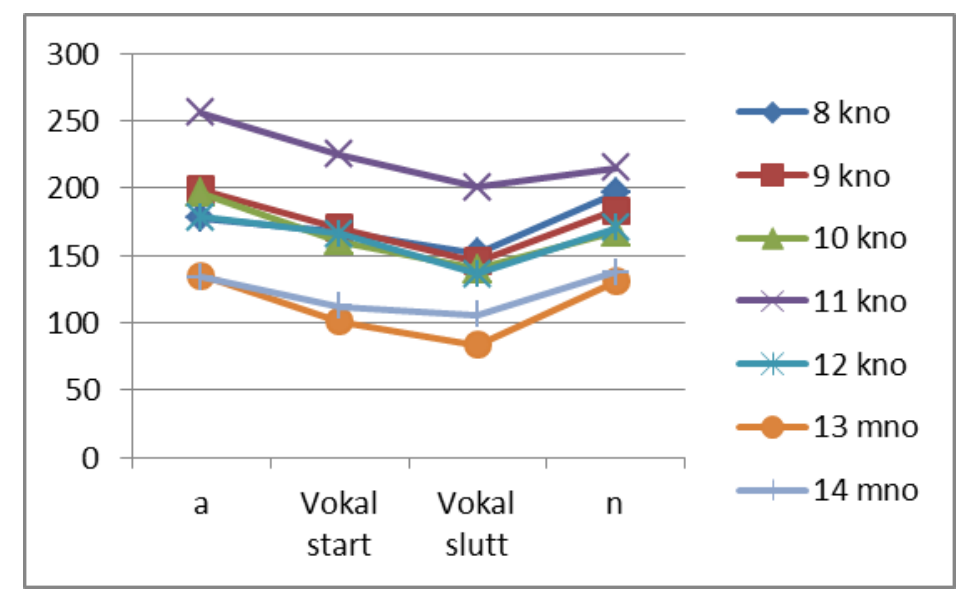

Aksent 1 - norske talere (barnet, maten, bilen, huset, varet)

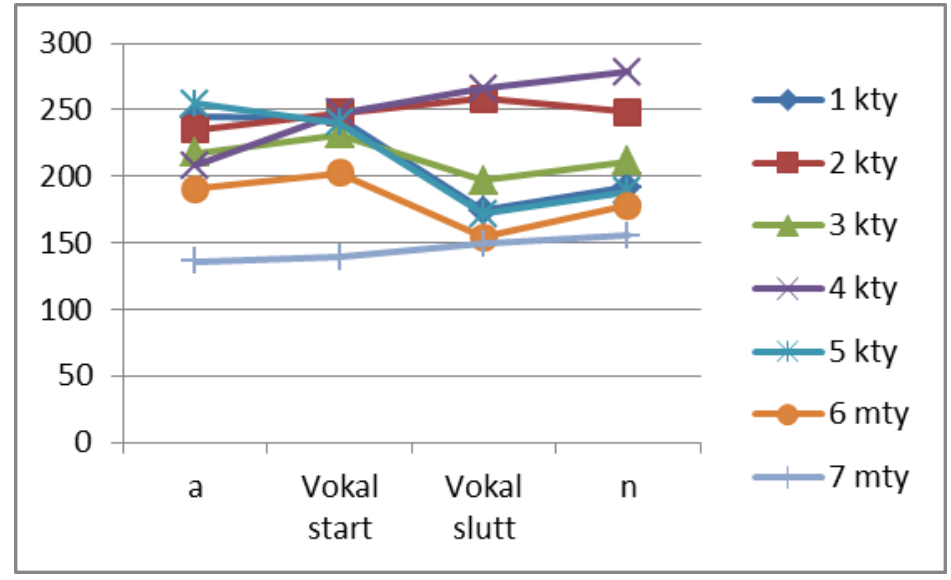

Aksent 2 - tyske talere (fine, pene, dyre, gule, sure)

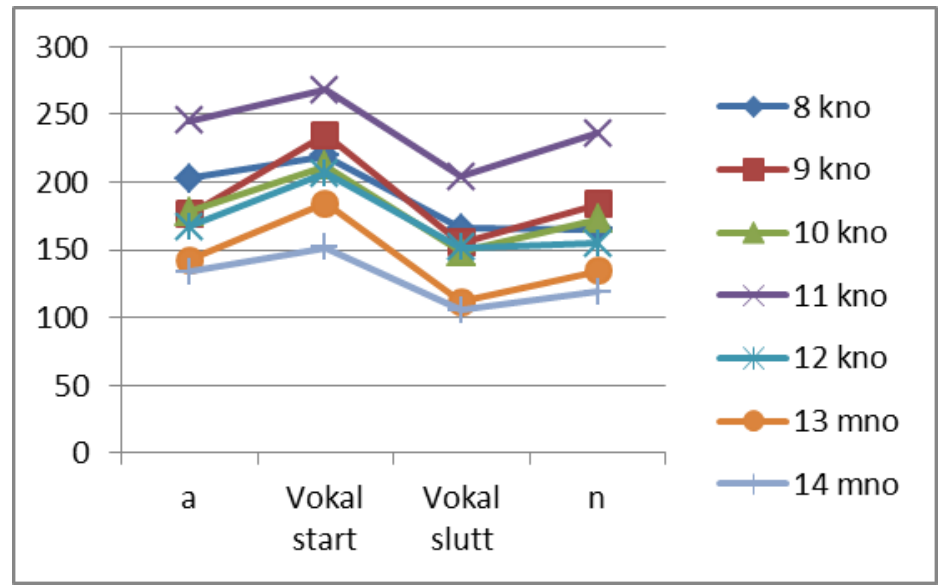

Aksent 2 - norske talere (fine, pene, dyre, gule, sure)

Figur 25: gjennomsnittlig tonegang for begge aksenter

\section{Uttaleopplæring og toneaksenter i undervisning}

Granskningen av toneaksentene i denne studien har fokusert produksjonen av de to østnorske toneaksentene hos S2-talere. Når det gjelder uttaleopplæring, er persepsjonen hos S1-talere av S2-taleres produksjon en 
viktig faktor å ha kunnskap om. Dessuten er persepsjon viktig for innlæring. Man har skilt mellom resepsjon og persepsjon slik at resepsjonen vil være lik for alle normalthørende, mens persepsjon av språklyd innebærer at språklyden analyseres og identifiseres i hjernen. Det er ikke full enighet om hva som bør komme først i uttaleopplæringen, persepsjon eller produksjon, eller sagt med andre ord «lytting først»metodikk eller artikulatorisk instruksjon og imitasjon som grunnleggende betingelser for taleferdigheter (se f.eks Husby \& Kløve 2001). Når det gjelder tilegnelse av toneaksentene må vi tro at både lyttig og imitasjon er viktige ferdigheter uavhengig av rekkefølge. I det følgende vil problemstillingen være rettet mot toneaksenter eller ikke i uttaleopplæringen?

I januar 1977 startet den svenske språkforskeren og andrespråkslæreren Olle Kjellin «Uttalskliniken» i Uppsala i Sverige. «Kliniken» skulle være et slags verksted for uttalereparasjoner, og snart hadde de en lang køliste av hjelpesøkende, og en ventetid på opp til ett år var vanlig (Kjellin 1978). At så mange utlendinger i Sverige den gang ønsket en slik hjelp, viser at uttaleopplæringen på språkkursene ikke var tilstrekkelig, og at en god svensk uttale var sterkt etterspurt av utlendinger. Situasjonen for utenlandske innlærere i Norge i dag 40 år etter at Kjellin startet sin uttaleklinikk, er fremdeles slik at om det hadde funnes en klinikk for uttalereparasjoner, hadde den sikkert ikke manglet kunder. Mange andrespråksstudenter sier at de stort sett har fått lite uttaleopplæring på vanlige norskkurs, og at begynnerbøkene i norsk legger liten vekt på uttale. Mitt inntrykk etter mange års erfaring som norsklærer for utenlandske studenter er at uttaleundervisning ofte nedprioriteres på bekostning av andre (helt relevante) undervisningsområder som grammatikk og vokabular. Dette er uheldig fordi voksne innlærere svært ofte mestrer uttalen dårligst, og uttalen er det språklige området som S2- talere alltid må eksponere i muntlig kommunikasjon, og som kan framkalle sosial stigmatisering.

Kjellin etterlyste metoder for uttaleundervisning og tilbød selv både en metode og et syn på språklæring. Metoden krever at den brukes i begynneropplæring for å lykkes helt, og at de innlærte mønstrene stadig må vedlikeholdes. Feilaktig innlært uttale er nesten et uoverstigelig hinder ifølge Kjellin. (Og mange norsklærere har vel erfart sannheten i det.) Når det gjelder synet på språklæring, så er hans språkinnlæringsfilosofi at man ikke kan lære noen et språk, men at han eller hun må lære seg det selv, og at bevissthet er det sentrale. Bevissthet om eget språk, bevissthet om det, eller de nye språkene man vil lære seg, er det viktigste. Og å bruke språket, ikke bare på kurs, og kanskje ikke først og fremst der. Lærerens oppgave blir å systematisere og korrigere innlærerens oppdagelser om språket.

Norske og svenske språkforskere og lærere vektlegger prosodi i uttaleopplæring. Til forskjell fra de aller fleste inkluderer Kjellin toneaksentene i begynneropplæringen, både på ordnivå og setningsnivå (Kjellin 1978, 2002). I Sverige (Thorén 2009) som i Norge (Husby \& Kløve 2001) ekskluderes toneaksentene i stor grad i begynneropplæringen. En grunn er at de to toneaksentene er ulike i forskjellige deler av landet (men det er også segmentinventaret), en annen grunn er at de fremstilles som en uhorvelig mengde regler. Thorén skriver «...efter ett tag märkte jag att Kjellin hade lite väl många regler för hur alla 
tonfall och stigningar skulle bli rätt. Var alla verkligen nödvändiga?» Thoréns konklusjon er at toneaksentene har liten funksjonell verdi i andrespråksopplæring. Denne konklusjonen ligger også til grunn for den forenklede prosodimodellen som presenteres av Husby og Kløve (2001:112). De sier at følgende ferdigheter som også danner grunnlaget for realiseringen av norsk talerytme, vil utgjøre minstekravet til uttalekompetansen til en minoritetsspråklig som snakker norsk:

1. Tydelig forskjell i prominens mellom trykksterk og trykksvak stavelse

2. Tydelig forskjell i varighet mellom lang og kort vokal i trykksterk stavelse

I en nylig utkommet artikkel har Jan Kristian Hognestad (2017) et interessant synspunkt på uttaleopplæring for andrespråkselever i norsk. Han skriver at det synes å hefte en «berøringsangst» ved intonasjon som emne i norsk som andrespråk. Grunnen kan være at norsk prosodi er vanskelig å gripe både for lærere og innlærere. Et eksempel på mangelfull formidling fra andrespråkslærere fra min egen erfaring er følgende: Jeg pleier å spørre utenlandske norskstudenter på ulike nivåer om hvor mange lange vokaler ordet «vokal» har. Som regel får jeg svaret «to». Begrunnelsen studentene gir, er at når vi skriver én konsonant, så skal vokalen foran uttales lang. Det som selvfølgelig mangler i dette svaret, er den helt grunnleggende forbindelsen mellom trykk og varighet i norsk som gjør at det bare er den siste vokalen /a/ som skal være lang. Hognestad hevder videre at det at norsk prosodi er vanskelig, særlig knyttes til toneaksentsystemet, som jo er særegent i europeisk språksammenheng. Og når lærere ikke gjør seg håp om at voksne andrespråkselever vil snakke norsk med toneaksenter, tematiseres intonasjonsrelaterte spørsmål nesten ikke i det hele tatt. Det at toneaksentene ikke tematiseres i uttaleopplæringen, $\varnothing$ ker derfor risikoen for at store deler av prosodien også usynliggjøres både i uttaleopplæringen og i diskusjonen om norsk som andrespråk. Det er faktisk slik at toneaksentene er intonasjonens helt essensielle ingrediens i de aller fleste varietetene av norsk gjennom konstitueringen av APer. Hognestad framhever også at andrespråkslærere bør være særlig oppmerksomme når de underviser voksne begynnerelever. Det er hos begynnerelevene lærere har størst mulighet til å påvirke med sin veiledning. Han mener at S2-brukere må bevisstgjøres om AP-konstituering, det vil si en hensiktsmessig fordeling av hovedtrykkstavelser, og at i hvert fall for viderekomne elever kan APer med korrekt toneaksentrealisering løftes opp på et metaspråklig nivå.

I sin lærebok Norsk fonetikk for utlendinger kaller andrespråkslærer og fonetiker Åse-Berit Strandskogen aksentfrasen for tonegruppe (Strandskogen 1979). I denne læreboka er det en trinnvis oppbygging mot en framstilling av og muntlige $\varnothing$ velser i norsk setningsprosodi der hovedtrykkstavelser og de to toneaksentene er i fokus. Likevel ligger hovedvekten i boka på fonemøvelser. Strandskogen bruker samme framstillingsmåte av de to toneaksentene som Kjellin: Ved å tegne inn aksentkurvene i tonegruppene (APene) får de fram sammenhengen mellom trykk, relativ tonehøyde og forløpet av kurvene. Her har man altså en metode for opplæring i og bevisstgjøring om toneaksentene. 
Selv om vi ikke vet hvor viktige toneaksentene er for norske førstespråksbrukere når de skal forstå og ikke minst vurdere S2-taleres norsk, har forskning vist at intonasjon og varighet bidrar til graden av utenlandsk aksent (uttalt /ak ${ }^{1} \mathrm{say} /$ ) og til hvor forståelig S2-uttale er (van Dommelen og Husby 2009; Holm 2008; Almberg og Husby 2000).

For brukere av norsk som S2 vil toneaksentsystemet naturlig nok by på ekstra utfordringer. Vi vet at prosodi er viktig for vår oppfatning av aksent, både utenlandsk og innenlandsk. Vi hører forskjell på en nordlending og en østlending, og vi hører ofte morsmålssubstrat hos den som snakker et fremmedspråk. Aksenten kan være med på å trekke oppmerksomheten bort fra innholdet i det som blir sagt. Det er en motsigelse i det å ville utsette innlæring av de to toneaksentene i uttaleopplæringen når man samtidig sier at feilinnlært andrespråksuttale nesten er umulig å endre senere. Vi bør finne fram til måter å integrere toneaksentene i begynneropplæringen uten at man bør lære bort en masse regler, men man bør gjøre andrespråkselevene (og andrespråkslærerene) oppmerksomme på at de to toneaksentene finnes, og de bør få en klar forståelse av forbindelsen til trykkstavelser og stavelsesvarighet. Dette tror jeg kan gi en sikrere vei mot en mest mulig aksentfri uttale som jo er et mål for mange utlendinger som lærer norsk. Jeg vil avslutningsvis sitere en utenlandsk student på uttalekurs ved UiO: «Da jeg lærte om de norske tonemene, falt den norske uttalen på plass.»

\section{Litteratur}

Almberg, Jørn \& Olaf Husby 2000: The relevance of some acoustic parameters for the perception of a «foreign accent». I: James, Allan \& Jonathan Leather (red.), New Sounds 2000, vol. 4. Proceedings of the Fourth International Symposium on the Acquisition of Second-Language Speech. University of Klagenfurt. 1-10.

Baumann, Stefan, Martine Grice \& Ralf Benzmüller (2000): GToBI - a phonological system for the transcription of German intonation. I Prosody (21-28)

Boersma, Paul \& David Weenink 2016: Praat: doing phonetics by computer [Computer program]. Version 6.0.19, retrieved from http://www.praat.org/

Fretheim, Thorstein \& Wim A. van Dommelen 2012: A pragmatic perspective on the phonological values of utterance-final boundary tones in East Norwegian intonation. The Linguistic Review 29 (4): 663-677

Hognestad, Jan K. 2009: Intonasjon som tekstbinding. Maal og Minne 2

Hognestad, Jan K. 2012: Tonelagsvariasjon i norsk. Synkrone og diakrone aspekter, med sarlig fokus på vestnorsk. Avhandling for graden philosophiae doctor. Universitetet i Agder. Fakultet for humaniora og pedagogikk.

Hognestad, Jan K. 2017: Prosodiske strategier i norsk som andrespråk. NOA norsk som andrespråk 1/2017: 63-84 
Holm, Snefrid 2008: Intonational and Durational Contributions to the Perception of Foreignaccented Norwegian. An Experimental Phonetic Investigation. Thesis for the degree of Philosophiae Doctor. NTNU Trondheim

Husby, Olaf \& Marit Helene Kløve 2001: Andrespråksfonologi. Teori og metodikk. Oslo: Ad Notam Gyldendal.

Jahr, Ernst Håkon \& Ove Lorentz (red./eds.) 1983: Prosodi/Prosody. Novus Forlag.

Kjellin, Olle 1978: Svensk prosodi i praktiken. Handledning i uttalsinlärning. Studieförlaget, Uppsala. Provupplaga

Kjellin, Olle 2002: Språket, uttalet och hjärnan. Uppsala: Hallgren \& Fallgren

Kristoffersen, Gjert 2000: The Phonology of Norwegian. Oxford: Oxford University Press.

Kristoffersen, Gjert 2006: Markedness in Urban East Norwegian tonal accent. Nordic Journal of Linguistics, 29, 95-135.

Kuronen, Mikko 2015: Tonaccenterna i avancerade finska inlärares svenska - en akustisk studie. NordandNordisk tidsskrift for andrespråksforskning, 10(1):53-80.

Lundemo, Frode 2003: “Deutsche Fonetik für “Tysk grunnfag””. Germanistisk institutt, Universitetet i Oslo. Ophaug, Wencke 2010: Sangfonetikk. En innføring. Fagbokforlaget Vigmostad \& Bjørke AS

Steien, Guri Bordal 2014: Andrespråkstoner gjennom førstespråkprosodi: en studie av ordmelodier i norsk spontan tale produsert av personer med lingala og swahili som S1. Nordand-Nordisk tidsskrift for andrespråksforskning, 9(2):9-30.

Steien, Guri Bordal \& Wim A. van Dommelen 2016: The production of Norwegian tones by multilingual non-native speakers. International Journal of Bilingualism 1-14. DOI:

10.1177/13670069166732181bj.sagepub.com

Strandskogen, Åse-Berit 1979: Norsk fonetikk for utlendinger. Gyldendal Norsk Forlag A/S.

Thorén, Bosse 2009: http://spraktidningen.se/print/artiklar/2009/02/ratt-betoning-gor-dig-forstadd

van Dommelen, Wim A. \& Olaf Husby 2009: Perception of Norwegian word tones by Chinese and German listeners. I: Watkins. Michael A, Andreia S Rauber \& Barbara O. Baptista (red.), Recent Research in Second Language Phonetics/Phonology: Perception and Production. Cambridge: Cambridge Scholars Publishing. 318-331.

Wang, Yue, Allard Jongman \& JoanSereno 2003: Acoustic and perceptual evaluation of Mandarin tone productions before and after perceptual training. Journal of the Acoustical Society of America 113, 1033-1043

Yip, Moira 2002: Tone. Cambridge University Press, New York 